\title{
Convergent geographic patterns between grizzly bear population genetic structure and Indigenous language groups in coastal British Columbia, Canada
}

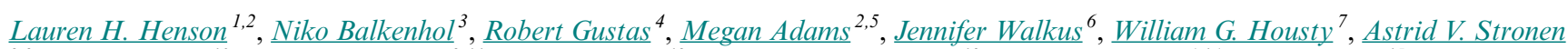

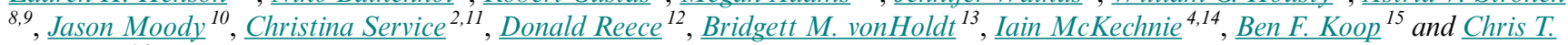 \\ $\underline{\text { Darimont }}^{1,2}$
}

\begin{abstract}
Landscape genetic analyses of wildlife populations can exclude variation in a broad suite of potential spatiotemporal correlates, including consideration of how such variation might have similarly influenced people over time. Grizzly bear (Ursus arctos) populations in what is now known as coastal British Columbia, Canada, provide an opportunity to examine the possible effects of a complex set of landscape and human influences on genetic structure. In this collaboration among the Nuxalk, Haílzaqv, Kitasoo/ Xai'xais, Gitga'at, and Wuikinuxv First Nations and conservation scientists, we characterized patterns of genetic differentiation in the grizzly bear, a species of high cultural value, by genotyping 22 microsatellite loci from noninvasively collected hair samples over a 23,500 $\mathrm{km}^{2}$ area. We identified three well-differentiated groups. Resistance surfaces, which incorporated past and present human use, settlement, and landscape resistant features, could not explain this pattern of genetic variation. Notably, however, we detected spatial alignment between Indigenous language families and grizzly bear genetic groups. Grizzly bears sampled within an area represented by a given language family were significantly similar to those sampled within that language family $(P=0.001)$ and significantly divergent to those sampled outside the language family $(P=0.001)$. This spatial co-occurrence suggests that grizzly bear and human groups have been shaped by the landscape in similar ways, creating a convergence of grizzly bear genetic and human linguistic diversity. Additionally, grizzly bear management units designated by the provincial government currently divide an otherwise continuous group and exclude recently colonized island populations that are genetically continuous with adjacent mainland groups. This work provides not only insight into how ecological and geographic conditions can similarly shape the distribution of people and wildlife but also new genetic evidence to support renewed, locally led management of grizzly bears into the future.
\end{abstract}

Key Words: biocultural diversity; grizzly bear (Ursus arctos) population genetic structure; landscape genetics

\section{INTRODUCTION}

This work is dedicated to the late Nuaqawa (Evelyn Windsor), who taught us that people learned their language and way of life from the bears.

Landscape genetic studies have traditionally focused on a limited suite of geographic and anthropogenic landscape features within narrow temporal scales to explain patterns of genetic structure. Recent land cover and land use are the most common variables examined, appearing in $83 \%$ of surveyed studies that investigated landscape effects on functional connectivity, followed by roads and similar linear features in $24 \%$ of studies (Zeller et al. 2012). Although roads can create significant resistance to gene flow (Epps et al. 2005, Riley et al. 2006), water bodies can also exert similar influence (Frantz et al. 2010, Hartmann et al. 2013), yet they are rarely considered. Further, although the influence of modern landscape resistant features on gene flow can be significant, some genetic markers can also be informative for archaeological timescales (Brown et al. 2009, Harris and Taylor 2010). Indeed, anthropogenically shaped landscapes of the past can leave signatures in population structure observed today
(Holzhauer et al. 2006), especially in species with long generation times (Spear and Storfer 2008, Zellmer and Knowles 2009).

Although anthropogenic settlement and land use are commonly included as resistance factors, human activities may not be categorically resistant, especially in historical timelines and considering less conflict-prone cultural approaches to coexistence (Clark and Slocombe 2009, Bhattacharyya and Slocombe 2017). For instance, whereas roads often pose barriers to gene flow, they are not equally and universally resistant (Frantz et al. 2012); indeed, some species use roads as movement corridors (Oleksa et al. 2015). Furthermore, historic human landscape use and settlement, even where dense, may not have the same resistance effects as modern anthropogenic use. For example, dense historic settlements had no effect on gene flow patterns in African elephant populations, whereas modern habitat selection patterns are best explained by contemporary settlement (Epps et al. 2013). The limited focus of many landscape genetic studies on modern land cover and linear features provides an opportunity for the inclusion of a broader suite of spatiotemporal geographic and anthropogenic variables.

\footnotetext{
${ }^{1}$ Department of Geography, University of Victoria, ${ }^{2}$ Raincoast Conservation Foundation, ${ }^{3}$ Wildlife Sciences, Faculty of Forest Sciences, University of Goettingen, ${ }^{4}$ Department of Anthropology, University of Victoria, ${ }^{5}$ Department of Forest and Conservation Sciences, University of British Columbia, ${ }^{6}$ Council, Wuikinuxv First Nation, ${ }^{7}$ Haítzaqv Integrated Resource Management Department, ${ }^{8}$ Department of Biology, University of Ljubljana, ${ }^{9}$ Department of Biotechnology and Life Sciences, Insubria University, ${ }^{10}$ Nuxalk Stewardship Office, ${ }^{11}$ Kitasoo/Xai'xais Stewardship Authority, ${ }^{12}$ Gitga'at Oceans and Lands Department, ${ }^{13}$ Department of Ecology and Evolutionary Biology, Princeton University, ${ }^{14}$ Hakai Institute, ${ }^{15}$ Department of Biology, University of Victoria
} 
Humans and human-human interactions not only shape landscapes (Power et al. 2018) but also can be shaped by the environment in similar ways to non-human animals. Broadly, this parallel response is so prevalent that it has resulted in global patterns of co-occurrence of biological diversity in wildlife and of linguistic diversity in human societies (Maffi 2005, Gorenflo et al. 2012). This co-location of biological (i.e., species) diversity and socio-cultural (i.e., cultural or linguistic) diversity occurs at local (Stepp et al. 2005), regional (Manne 2002), and global scales (Gorenflo et al. 2012). For example, in North America north of Mexico, high human linguistic, ethnolinguistic, and cultural diversity were all significantly correlated over space with high species diversity of trees (Smith 2001). As a component of cultural diversity, spatial patterns in linguistic diversity have been found to originate from long-term social interactions that relate to variation in a suite of biophysical factors, including geographic distance (Honkola et al. 2018), topography (Axelsen and Manrubia 2014), resource productivity (Codding and Jones 2013), and resource diversity (Moore et al. 2002). Although biophysical factors can influence and shape linguistic diversity over time, spatial patterns of linguistic diversity also reflect an enduring history of socio-cultural interaction and integration of communities of speakers. Our objective is to contribute to a small but growing body of work (e.g., Polfus et al. 2016, Schulz et al. 2019, Gagnon et al. 2020) investigating if and how spatial patterns in fine-scale components of the biocultural relationship, i.e., human linguistic diversity and wildlife genetic diversity, might align.

Grizzly bears (Ursus arctos) in the Central Coast region of what is now known as British Columbia (BC), Canada, have shared habitat and resources with people on the landscape for millennia. Indigenous oral histories and songs from the region depict grizzly bears as kin and cultural or customary enforcers for their human neighbors (Housty 2014). Today, the Nuxalk, Haíłzaqv, Kitasoo/ Xai'xais, Gitga'at, and Wuikinuxv Nations are increasingly engaging in Nation-led scientific research and management regarding land-use planning, fisheries management, and coexistence strategies with grizzly bears and black bears ( $U$. americanus) in the region. Given the scholarly, management, and cultural context, the coastal grizzly bear system presents unique opportunities: (1) to examine the potential for genetic structure in a highly mobile species with a diversity of potential drivers over long time scales, (2) to investigate possible associations between genetic structure and Indigenous cultural diversity in the area, and (3) to assess the appropriateness of current management unit designations with regard to genetic diversity in a species of conservation concern.

A variety of factors has likely shaped biocultural variation on the Central Coast. In this region, industrial disturbance and road networks are limited, with a complex coastline comprising many channels, inlets, and estuaries that may supplant roads (Boulanger and Stenhouse 2014, Proctor et al. 2020) as key linear features potentially affecting wildlife genetic structure. Additionally, the spatiotemporal influence of human activity on wildlife has been dynamic and complex in this region. For millennia (McLaren et al. 2015), Indigenous peoples and their seasonal settlements occurred broadly uninterrupted and in high densities. On Triquet Island, for example, an archaeological excavation co-led by the Haíłzaqv Integrated Resource Management Department and
Hakai Institute researchers at the University of Victoria found evidence of human occupation dated to approximately 14,00013,700 years ago (McLaren et al. 2020), indicating the presence of the Haítzaqv people in this area since time immemorial (McLaren et al. 2015).

In recent history, however, pronounced changes have occurred in human presence, activity, and interaction with wildlife. Within the most recent two centuries, violence- and disease-mediated genocide following European colonization reduced Indigenous populations by orders of magnitude and interrupted their role as prominent ecological agents within these coastal temperate rainforests (Harris 1994, McLaren et al. 2015). A conservative estimate of the population of the Northwest Coast of North America numbered $>180,000$ people during the late 1700 s, whereas less than a century later, only 35,000 people remained (Boyd 1999).

Despite these recent changes, such previously high-density societies, particularly when they had strong resource use overlap with bears over millennia, might have influenced bear movement and gene flow. The density of resources and high-relief topography of the Central Coast of $\mathrm{BC}$ in combination with the long-term establishment of Indigenous territories and autonomy, despite extensive cultural exchange, enabled a rich diversity of distinct Indigenous language families, languages, and dialects to develop in parallel over numerous generations (Nichols 1992, Beck 2000). Given broadly similar mobility and foraging ecology between bears and Indigenous peoples of the area over millennia, as well as evidence of co-locations of biological and cultural diversity elsewhere (e.g., Maffi 2005), we might expect similar spatial patterns defining bear genetic and Indigenous linguistic groups. Such an association could be mediated through two processes, which are not mutually exclusive: (1) combinations of biophysical factors resistant to people and bears created boundaries among both human linguistic and bear genetic groupings (Nichols 1992, Axelsen and Manrubia 2014), and (2) broader spatial patterns in ecological heterogeneity (i.e., in the distribution of food and other resources) that may have, in part, structured humans and their language cultures also structured grizzly populations (Maffi 2005, Muñoz-Fuentes et al. 2009, Housty et al. 2014).

Relationships between grizzly bears and humans in a contemporary management context also motivated our research collaboration and this specific work. We aimed to examine grizzly population genetic structure data to evaluate the spatial designation of grizzly bear population units (GBPUs) identified by the provincial government along the Central Coast of $\mathrm{BC}$. Although the designation of GBPUs in southern BC considers the consequences of landscape and anthropogenic factors on genetic isolation, neither genetic diversity nor genetic structure are currently considered in the designation and management of the remote GBPUs of the Central Coast; boundaries are instead defined primarily by heights of land separating watersheds (Province of British Columbia 2012). Accordingly, evidence from genetic data could refine these management units to inform longterm management and conservation and ensure the viability of grizzly bear populations in this region. Such management is increasingly led by Indigenous Stewardship offices (Artelle et al. 2019). 
Against this background, we formed a number of analytical hypotheses to guide our investigation. Given the mobility of grizzly bears, the modest spatial scale of the study area, and the relatively homogenous resource distribution across the study area, we hypothesized that genetic structure analysis would reveal a semicontinuous population influenced by both landscape and anthropogenic variables (past and present). Specifically, we expected large waterways (Paetkau et al. 1998a), rugged terrain (Proctor et al. 2012, Lewis et al. 2015), and the presence of snow and ice (Lewis et al. 2015) to impose potential resistance to gene flow. Predicting responses to human activity in recent and more distant periods was more difficult. We hypothesized that contemporary human settlement (Proctor et al. 2012) and industrial forestry (Apps et al. 2004) could impose resistance to gene flow, but acknowledged that overall human density and industrial activity on the landscape today is limited. Similarly, we predicted that the dense and widespread presence of Indigenous peoples and communities over the past several millennia may have affected gene flow, but we recognize that cultural norms, which prioritize coexistence (Housty et al. 2014), might have limited such effects. Considering this complex background, our models included the possible resistance provided by archaeologically recorded, pre-industrial, Indigenous settlement sites and present human settlement and activity. Finally, given the aforementioned rich diversity of coastal Indigenous languages, shared ecological niche, potentially similar responses to biophysical factors, and kincentric relationship between bears and Indigenous peoples in coastal BC, we also hypothesized that there could be a spatial association between bear genetic groups and Indigenous language families.

\section{METHODS}

\section{Study area and sample selection}

The study area included the approximate parallelogram bound by Kitimat in the northeast $\left(54.065931^{\circ},-128.637305^{\circ}\right)$, Hartley Bay in the northwest $\left(53.424609^{\circ},-129.253510^{\circ}\right)$, Bella Coola in the southeast $\left(52.372887^{\circ},-126.753763^{\circ}\right)$, and Bella Bella in the southwest $\left(52.160251^{\circ},-128.145238^{\circ}\right)$. We incorporated an additional 200-km buffer (excluding open ocean areas; Fig. 1) to account for bear movement, which was informed by grizzly bear home range data collected from the $\mathrm{BC}$ interior $\left(187 \mathrm{~km}^{2}\right.$ for males and $103 \mathrm{~km}^{2}$ for females; Ciarniello et al. 2007) and southern Alaska (93-623 km² for females; Collins et al. 2005). From within the buffered study area, we noninvasively collected hair samples from 82 hair snag stations between 2006 and 2017 ( $N=125$; Service et al. 2019) and hair samples from British Columbia Ministry of Environment compulsory inspections of hunted bears $(N=22)$. The full sample set consisted of 63 females and 84 males. Noninvasive samples were chosen using a conservative $25 \mathrm{~km}^{2}$ grid to represent the average range size of females with cubs in steep mountainous terrain (Boulanger et al. 2006). Where possible, we chose the male and female samples that were closest to the centroid of the grid, resulting in two samples per grid square. Compulsory Inspection Database (CID) samples were gathered via a datashare agreement with the Ministry of Environment and represent hair samples taken from hunted bears from 2002-2016 within the Central Coast area of interest. CID samples were added to augment the sampling set in the northern portion of the study area.
Fig. 1. Map of the study area. The study area parallelogram (yellow), which contains all samples $(N=147)$, on background map (Google Earth Pro version 7.3) is bounded by Kitimat, Hartley Bay, Bella Bella, and Bella Coola, with a 200-km buffer (brown), excluding open ocean, for the creation of resistance surfaces. The inset map situates study area and buffer within North America.

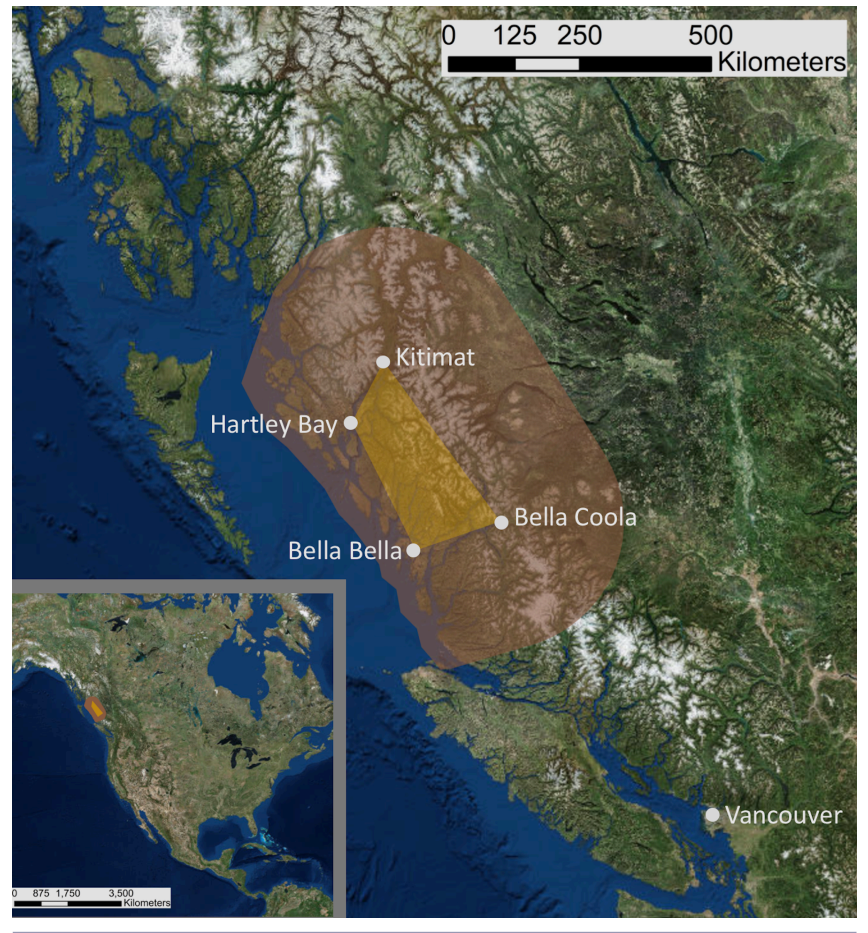

Hair snag stations were part of a long-term bear monitoring project in collaboration with the Nuxalk, Haílzaqv, Kitasoo/ Xai'xais, Gitga'at, and Wuikinuxv Nations, covering $23,500 \mathrm{~km}^{2}$ of coastal BC. This multi-Nation collaboration that extends to partnering academia and of which this genetics research project is part, is a multifaceted, applied, and scholarly collection of research and management activities. Extensive background about how the voices of the communities, their history, and their relationships with grizzly bears and the environment influence this program is covered in depth elsewhere (Adams et al. 2014, Housty et al. 2014; Artelle et al., unpublishedmanuscript). Broadly, this partnership, now a decade old, aligns with recent literature on biocultural research approaches that support equitable decision-making and connecting knowledge to actions (Groffman et al. 2010, Pretty 2011, Smith et al. 2013). Specifically and briefly, applied research on bears in the area was initiated with a project by a Haílzaqv nonprofit (QQS Projects Society) and led by a Haíłzaqv scientist and manager (Housty et al. 2014). The Bear Working Group, a formal advisory group consisting of the four Central Coast Nations following Indigenous protocols of collaboration, was formed in 2011 to conduct research and inform Indigenous decision-makers on hunting, salmon, and forest management. Individual Nations participating in the Bear Working Group created and continue to oversee long-term noninvasive bear monitoring projects tailored to the needs of 
individual partnering communities, in collaboration with academics and conservation scientists from the Raincoast Conservation Foundation and the Applied Conservation Science Laboratory at the University of Victoria. Research questions are co-developed through a combination of community meetings, detailed collaboration with Stewardship offices, and a yearly "international" Bear Working Group meeting. Methods and results are shared throughout the design and analysis phases. Consultation continues into manuscript preparation, and all Stewardship departments of territories containing sampling locations approved the submitted version of this manuscript. The trajectory of all constituent projects are shaped to meet the management goals of individual communities, the long-term monitoring goals of the Bear Working Group, and often, but not always, the requirements of graduate student programs (Adams et al. 2014). The larger scale suite of interlocking bear monitoring projects is thus partnered at both local and Central Coast scales, encompassing issues of interest to individual Nations and questions that span multiple communities and institutions (Adams et al. 2014; Artelle et al., unpublished manuscript).

The genetics research described here was initiated because of interest expressed by several participating Nations in understanding the ancestry of grizzly bear individuals colonizing islands off the Central Coast (Service et al. 2014). Additionally, this project was intended to address the long-term monitoring goals of the Bear Working Group by identifying empirically informed spatial population units for management, given that existing Provincial GBPUs were created in the absence of local data. Accordingly, from project initiation to interpretation of results, the voices of participating community members are included in this scholarly form of dissemination, which complements important "inreach" and policy development activities of participating Nations.

\section{DNA extraction and microsatellite genotyping}

DNA extraction, amplification, and sequencing were conducted by Wildlife Genetics International in Nelson, BC. We extracted DNA from selected hairs with a Qiagen DNeasy Blood and Tissue Kit (Qiagen, Maryland, USA) using the spin column protocol with a double elution (for detailed extraction methods, see Appendix 1).

To identify fine-scale population structure, we combined 13 microsatellite loci (G10J, G10H, G10U, CXX110, CXX20, MU23, MU50, MU59, MU51, CPH9, 144A06, MSUT-2, and 145P07) previously applied to grizzly bear population structure research (Fredholm and Winterø 1995, Paetkau et al. 1998a, Kitahara et al. 2000, Bellemain and Taberlet 2004, Proctor et al. 2012, Kamath et al. 2015) with an eight-loci (G1A, G1D, G10B, G10C, G10L, G10M, G10P, and G10X) microsatellite set previously used for individual identification (primers are provided in Table A1.1 in Appendix 1; Paetkau et al. 1995, 1998b). Samples were sequenced using an Applied Biosystems 3100XL sequencer, and we scored genotypes using Genotyper software (Applied Biosystems, Foster City, CA). We determined sex using an amelogenin locus that has different transcripts for $\mathrm{X}$ and $\mathrm{Y}$ chromosomes (Ennis and Gallagher 1994; for detailed PCR and quality control protocols, see Appendix 1).

\section{Population genetic analyses}

We estimated observed and expected heterozygosity per population using the R package "adegenet" (Jombart 2008; see Appendix 1 for tests for Hardy-Weinberg proportions). To identify the spatial pattern of grizzly bear population structure, we calculated the mean center of all detections per individual and employed one frequentist and two Bayesian methods. We first conducted a spatial principal components analysis (sPCA), which is a frequentist, non-model based approach that does not rely on Hardy-Weinberg assumptions conducted in $\mathrm{R}$ version 3.2.4 ( $\mathrm{R}$ Core Team 2018) using the "adegenet" package with a Delauney triangulation, with eigenvalues chosen interactively and data not scaled to unit variance. To complement the frequentist, spatially explicit PCA, we also implemented a model-based Bayesian clustering algorithm without a priori populations, because of no prior knowledge of genetic groupings, using the software STRUCTURE (Pritchard et al. 2000) with the parameters USEPOPINFO $=0$, MAXPOPS $=6$, NOADMIX $=0$, ALPHA $=1$, with 10 iterations of 50,000 burn-ins and 450,000 Markov chain Monte Carlo repetitions. These parameters were selected following the guidance of Porras-Hurtado et al. (2013) in accordance with our sample numbers, loci set, possible estimated maximum number of populations given the relatively small geographic area, and realistic probability of admixture among genetic groups. To account for potential unbalanced sampling, we conducted an additional analysis by adjusting alpha to 0.17 (Wang 2017). We determined the appropriate number of populations $(K)$ using Delta $K$, a second-order change rate in likelihood that peaks at the most probable $K$ as implemented in Structure Harvester (Evanno et al. 2005, Earl and vonHoldt 2012). To represent STRUCTURE results visually, we interpolated population $Q$-values (individual cluster membership proportions) using the inverse distance weighting (IDW) method, which uses the assumption of spatial autocorrelation to interpolate values across unmeasured areas, in ArcGIS 10.3. We combined IDW surfaces for all populations using the Composite Bands function (Chiocchini et al. 2016). We used Geneland version 4.0.6 (Guillot et al. 2005) as an additional Bayesian spatially explicit clustering program with default parameters to assess up to 10 genetic partitions with no uncertainty on coordinates, 100,000 iterations, 100 thinning, and an uncorrelated allele frequency model. We did not calculate $F_{\mathrm{ST}}$ (or analogs) because of the potential that our microsatellite markers and observed populations do not follow the assumptions of a stepwise mutation model (Meirmans and Hedrick 2011) and have a higher migration than mutation rate (Wright 1943, Balloux and LugonMoulin 2002). Because of their geographic isolation, we removed 22 CID samples from Kitimat from further analyses, resulting in 128 samples $(N=125$ noninvasive hair samples, $N=3$ CID samples) for connectivity and resistance estimation. We imposed a map of GBPUs onto the map of the IDW-interpolated STRUCTURE $Q$-values to assess visually the extent of overlap between genetic group and GBPU boundaries.

\section{Landscape variables}

Based on the literature (Nichols 1992, Paetkau et al. 1998a, Apps et al. 2004, Proctor et al. 2012, Axelsen and Manrubia 2014, Lewis et al. 2015), we created resistance layers for the variables we expected to affect grizzly bear gene flow. All layers are in the EPSG:3005 coordinate system with the NAD83 datum and BC 
Albers Equal Area projection. The layers included terrain ruggedness, waterways (Geospatial Data Downloads 2018), ice and snow (Government of Canada 2015), archaeological (preindustrial) anthropogenic settlement as indicated by the presence of recorded shell midden deposits and fish traps documented during archaeological survey efforts (primary sources in Table A1.2 in Appendix 1), and modern anthropogenic disturbance in the form of a simple variable indicating either presence or absence of forestry activity (Hermosilla et al. 2018), as well as current settlement defined by pockets of human-dominated areas (Province of British Columbia 2016). We acknowledge that recorded archaeological sites are subject to the uneven distribution of survey effort, do not encompass all archaeological research in the area, and likely represent only a small proportion of actual habitation and use.

Although harvesting of grizzly bears occurred on the Central Coast in historic and modern times, we infer from data described below that its influence on genetic structure was minimal, and thus, we did not consider its potential effects in our analyses. An analysis of animal remains recovered in archeological sites suggests that black bears were killed during the PleistoceneHolocene transition in Haida Gwaii (McLaren et al. 2005), and the only excavated archaeological site in the study area with identified bear bones contained a small number of remains from black bears only (Cannon 1991). In the 1800s, the Hudson Bay Company had trading posts on the coast. Although grizzly bears were clearly killed by commercial hunters and trappers, they were not a preferred target (Meilleur 2002). During much of the past century, when hunting was managed by the Province, only a relatively small part of our study area (the Bella Coola valley) showed evidence of recent overexploitation (Artelle et al. 2013). This limited contemporary harvest on the Central Coast is likely associated with restricted access because of the near absence of roads. Given this extended history of intermittent and generally low levels of killing, we reason that hunting has had minimal influence on genetic structure compared to continuous factors such as landscape resistance and habitat fragmentation (McLellan et al. 2019).

Recognizing a visual overlap between Indigenous language family boundaries and the identified bear genetic groups, we also considered the approximate physical location (i.e., linear extent) of the boundaries of Indigenous language families on the Central Coast as representative of a potentially unique combination of biophysical factors that may be resistant to both people and bears (Nichols 1992, Axelsen and Manrubia 2014). These boundaries did not spatially align completely with any other single considered resistance factor, supporting their inclusion as a unique variable. We considered multiple sources, which generally align, to define extents and boundaries among language families. The boundaries we used (digitized from Lepofsky and Turner 2013) are largely consistent with the First Peoples' language map of BC (First Peoples' Culture Council of British Columbia 2020), and are based on older linguistic renderings of relationships among language families with updated spellings and place names (Thompson and Kinkade 1990, Beck 2000). As background to their estimation and in the absence of written records, modern and historic relationships among individual languages and language families have been gleaned through analyses of typological and grammatical similarities (Thomason and
Kaufman 1988). The Salishan language family (here referred to as Salishan Nuxalk due to the inclusion of It7Nuxalkmc or Nuxalk in English, the language of the Nuxalk Nation) diverges strongly from the two other language families in the study area, i.e., the Tsimshian and Wakashan language families, which were identified as fundamentally distinct linguistic groups from the late 1800s (Tolmie and Dawson 1884, Boas 1887); relationships among other language families on the coast were refined and debated through later research (Swadesh 1951, Thomason and Kaufman 1988, Thompson and Kinkade 1990). Although classified only relatively recently by linguists, language family boundaries on the Central Coast have a deep history (Embleton 1985), which is supported by archaeological and oral history evidence of long-term human occupation (Cannon 2003, McLaren et al. 2015). The categorization of this area as part of a larger residual zone (an area defined by diverse coexisting languages maintained by an established intergroup equilibrium) provides some evidence that the pattern of linguistic distribution may be older because of the long time periods typically needed to form an equilibrium and foster grammatical autonomy in language groups (Nichols 1992). These language families have considerable meaning and place-specific relevance to Nations participating in this work, with Gitga'at and Kitasoo members speaking languages in the Tsimshian family; Haítzaqv, Wuikinuxv, and Xai'xais Nations using languages encompassed by the Northern Wakashan family; and the Nuxalk Nation represented by the Salish-isolate Salishan Nuxalk family. Although spellings can differ within and among languages, grizzly bears are known as Nan in the Haítzaqvla, It7Nuxalkmc, 'Wuikala, and Xai'xais languages spoken by the Haíłzaqv, Nuxalk, Wuikinuxv, and Xai'xais Nations, respectively. In the Sgüüxs language of the Kitasoo Nation and the Sm'algyax language of the Gitga'at Nation, grizzly bears are known as Medi'ik.

The delineation of language family boundaries in this study was made with the understanding that these boundaries are fuzzy, imperfectly resolved, and potentially reflect a relatively limited temporal depth. Additionally, human travel and exchange among neighboring linguistic groups was common, and many individuals likely had fluency in multiple languages (Ames 2002). Given this information, we used analysis methods focused on either a rough approximation of these language family borders or the entire spatial area encompassed by each of the three language families. We additionally emphasize that the focus of this work is on the identification of bear genetic patterns and the factors potentially underlying them. Although we identify spatial alignment between language families and bear genetic groups, the focus on bear genetic data limits our ability to comment extensively on the derivation of language family boundaries.

\section{Connectivity and resistance estimation}

We assigned categorical resistance values to variables on a scale of 1 (very low) to 5 (maximum; Table 1), which assisted in our ability to compare resistance surfaces. Because of the potential importance of waterways on the coast, we tested an additional parameterization scheme with all waterways assigned a maximum resistance value of 5 and all other landscape cells assigned a value of 1 . We used the circuit theory-based software program Circuitscape version 4.0.5 (McRae et al. 2008b) to translate surface resistances into estimates of connectivity (McRae et al. 
Table 1. Resistance parameterization scheme, scale of resistance values, and attributes corresponding to resistance levels 1-5 for each variable.

\begin{tabular}{|c|c|c|c|c|c|c|c|}
\hline $\begin{array}{l}\text { Resistance } \\
\text { value }\end{array}$ & Ruggedness $^{\dagger}$ & $\begin{array}{c}\text { Water } \\
\text { Barriers }\end{array}$ & Ice and Snow ${ }^{\dagger}$ & $\begin{array}{c}\text { Modern } \\
\text { Settlement }^{\S}\end{array}$ & $\begin{array}{c}\text { Modern Disturbance } \\
\text { (Forestry) }\end{array}$ & $\begin{array}{c}\text { Archaeological } \\
\text { Settlement }\end{array}$ & $\begin{array}{c}\text { Indigenous } \\
\text { Language Families }\end{array}$ \\
\hline 1: very low & Level/nearly level: $0-116 \mathrm{~m}$ & $<2 \mathrm{~km}$ & - & - & - & - & - \\
\hline 2: low & Slightly rugged: $117-161 \mathrm{~m}$ & - & - & - & - & - & - \\
\hline 3: moderate & $\begin{array}{l}\text { Intermediately or moderately } \\
\text { rugged: } 162-497 \mathrm{~m}\end{array}$ & $2-7 \mathrm{~km}$ & - & - & - & - & - \\
\hline 4: high & Highly rugged: 498-958 m & - & - & $\begin{array}{l}\text { 500-m buffer } \\
\text { from } \\
\text { settlement }\end{array}$ & $\begin{array}{c}\text { Cells containing } \\
\text { anthropogenic } \\
\text { disturbance (forestry) }\end{array}$ & $\begin{array}{l}\text { 500-m buffer } \\
\text { from middens or } \\
\text { fish traps }\end{array}$ & - \\
\hline 5: maximum & Extremely rugged: $959-4367 \mathrm{~m}$ & $>7 \mathrm{~km}$ & $\begin{array}{c}\text { Cells } \\
\text { intersecting } \\
\text { snow and ice }\end{array}$ & $\begin{array}{c}\text { Cells } \\
\text { intersecting } \\
\text { settlements }\end{array}$ & - & $\begin{array}{l}\text { Cells intersecting } \\
\text { middens or fish } \\
\text { traps }\end{array}$ & $\begin{array}{c}\text { Cells intersecting } \\
\text { linear boundaries of } \\
\text { language families }\end{array}$ \\
\hline \multicolumn{8}{|c|}{$\begin{array}{l}\text { 'Lewis et al. (2015). } \\
{ }^{8} \text { Paetkau et al. (1998a). } \\
{ }^{8} \text { Proctor et al. (2012). } \\
\text { 'Apps et al. (2004). } \\
\text { "Nichols (1992) and Axelsen and Manrubia (2014). }\end{array}$} \\
\hline
\end{tabular}

2008a). Unlike least-cost path analysis that assumes an individual has perfect knowledge of the path of least resistance between origin and destination points (Gustas and Supernant 2019), electrical circuit and random walk theory investigates all possible paths and conveys connectivity between nodes as currents and voltages (McRae et al. 2008a). We analyzed each resistance surface individually in pairwise low memory mode, with a focal node file containing a unique identifier (individual number) and the geographic coordinates of the mean detection location of the individual (McRae et al. 2008a). We used the resulting matrices of effective distances as our landscape variable matrices for subsequent exploration of the relative contribution of each variable to the observed pattern of genetic variation.

To validate the resistance surfaces, we constructed a Euclidean distance matrix of $Q$-values assigned by STRUCTURE as the dependent variable of genetic distance (Balkenhol et al. 2014). The resulting genetic distance matrix was used in the statistical validation of matrices of effective distances created by the input of resistance surfaces into Circuitscape. Because of high multicollinearity between significant variables identified by Mantel tests (Appendix 1), we used commonality analysis (CA), which employs variance partitioning to address collinearity issues (Prunier et al. 2015). Although CA parsed out the unique and common contribution of each variable, the high collinearity of the top two landscape variables (one being geographic distance) made interpretation of their respective contributions difficult. This result prompted us to remove the apparent effect of isolation by distance in our data set to avoid erroneously inflating the explanatory power of the other landscape variables.

Finally, to partial out the effect of geographic distance, we calculated the residuals from a linear regression of each landscape variable using the $l m$ and residuals functions in the $\mathrm{R}$ package "stats". This procedure allowed us to identify the unique contribution of variables to the pattern of genetic structure while accounting for the contribution of geographic distance (i.e., isolation-by-distance). The variable residuals were combined using CA with logistic regression on distance matrices (LRDM) with the CAlrdm function, with 1000 bootstrap iterations and 10,000 permutations for tests of significance. Within the CAlrdm framework, we tested two separate models: an "archaeological" resistance surface that included landscape (waterways, snow and ice, terrain ruggedness) and anthropogenic (middens, fish traps, Indigenous language family boundaries) variables, and a "modern" surface containing the same landscape variables plus modern anthropogenic variables (human dominated areas, forestry).

\section{Statistical analysis of language family overlap with bear genetic groupings}

In addition to testing the hypothesis that the linear extents of human language family boundaries represent potentially resistant areas to grizzly bear gene flow, we tested for the overall overlap and similarities in spatial structuring among Indigenous language families and bear genetic groups using analysis of similarities (ANOSIM) and multivariate analysis of variance (MANOVA). We chose to use broader Indigenous language families rather than individual languages and territories because of their deeper temporal scale and more stable nature (Beck 2000, Lepofsky and Turner 2013). Using this map, bears were assigned to language family using their mean center of detection. We tested if bears within each language group had more similar $Q$-values to other bears within that language group or to members of another language group. We analyzed three language family categories and the Euclidean distance matrix of STRUCTURE $Q$-values for ANOSIM within the R package "vegan". To complement ANOSIM, we used MANOVA, which uses $Q$-values representing each bear genetic group assignment and language family categories to test for dissimilarities in $Q$-values between each language family. We did not remove the effect of geographic distance from these analyses because their purpose was to identify similarities in structure between bear and human groups, not to determine the contribution of these language groups to the pattern of bear genetic structure or vice versa. Additionally, given the innate importance of geographic distance in structuring Indigenous languages (Creanza et al. 2015), the removal of geographic distance patterns would likely remove important variation in language grouping. Furthermore, significant spatial overlap of bear genetic groups and human language groups may be due to a convergent response to the effects of geographic distance. 


\section{RESULTS}

\section{Central Coast grizzly bear genetic groups}

Grizzly bears on the Central Coast form three distinct genetic groups. STRUCTURE identified $K=3(\mathrm{G} 1, \mathrm{G} 2, \mathrm{G} 3)$ as the most likely number of genetic partitions, with high average cluster assignments $\left(Q_{\mathrm{G} 1}=0.92, Q_{\mathrm{G} 2}=0.91, Q_{\mathrm{G} 3}=0.87\right.$; Fig. 2 ; Fig. A 1.1 in Appendix 1). We also identified $K=3$ as the best fit partition when we implemented STRUCTURE with alpha $=1 / \mathrm{k}$. Interpolation of STRUCTURE $Q$-values aided in visually identifying the geographic locations of boundaries among genetic groups (Fig. 2). We corroborated this genetic and geographic structural pattern by the additional Bayesian spatially explicit clustering algorithm implemented in Geneland (Fig. A1.2 in Appendix 1). Geneland confirmed the presence of three genetic groups identified by STRUCTURE and the locations of breaks among them. The sPCA also identified boundaries in population structure concordant to those identified by Bayesian approaches (Fig. A1.3 in Appendix 1). We did not identify any difference in sPCA structural patterns when samples were separated by sex (Figs. A1.4 and A1.5 in Appendix 1). Collectively, we identified three distinct genetic groups with clearly defined boundaries appearing primarily along waterways (Fig. 2). When we investigated the provenance of island individuals, we found that most bears detected on islands $(N=18$ of $24 ; 75 \%)$ belonged to the nearest mainland genetic group, which is consistent with recent field observations and Indigenous knowledge, as well as inferences that grizzly bears have been actively colonizing islands in the recent past (Service et al. 2014).

Fig. 2. Plots of grizzly bear genetic and Indigenous language family overlap. Plots are STRUCTURE bar plot at $K=3$ (A) and combined $(\mathrm{B})$ and separate $(\mathrm{C})$ inverse distance weightinginterpolated STRUCTURE population $Q$-value maps (blue = $\mathrm{G} 1$, green $=\mathrm{G} 2$, red $=\mathrm{G} 3$ ). . Dark grey lines indicate borders among Indigenous language families (approximate overlap: blue $=$ Tsimshian, green $=$ Wakashan, red $=$ Salishan Nuxalk ; light grey points indicate mean detection locations of individual grizzly bears.

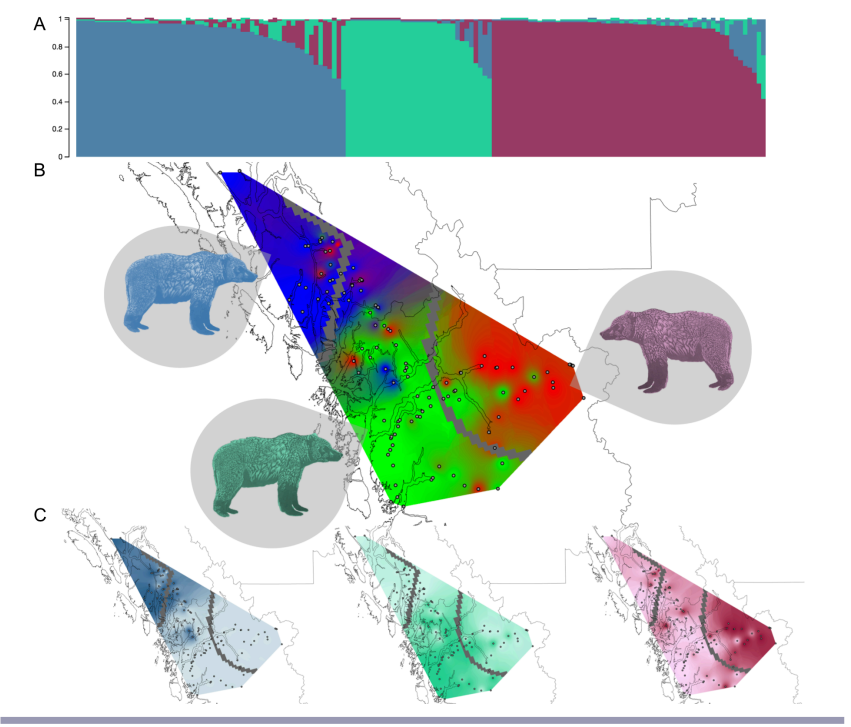

We also examined the overlap between the most likely number of genetic partitions and the geography of BC provincial GBPU designations (Province of British Columbia 2012). An overlay of the genetic partitions onto the IDW-interpolated map of population genetic structure revealed some inconsistencies (Fig. 3). We identified an overlap with the boundary between G2 and G3 and the GBPU boundary, but a mismatch with the boundary between $\mathrm{G} 1$ and $\mathrm{G} 2$. This mismatch results in the split of the otherwise continuous $\mathrm{G} 2$ group, with 16 of $58(28 \%)$ individuals assigned to $\mathrm{G} 2$ isolated within a separate GBPU.

Fig. 3. Map showing grizzly bear population genetic structure and grizzly bear population unit (GBPU) management boundaries. Inverse distance weighting-interpolated STRUCTURE population $Q$-value map shows grizzly bear populations (blue $=\mathrm{G} 1$, green $=\mathrm{G} 2$, red $=\mathrm{G} 3$ ). Dark grey lines $=$ GBPU boundaries; light grey points = individual mean detection locations.

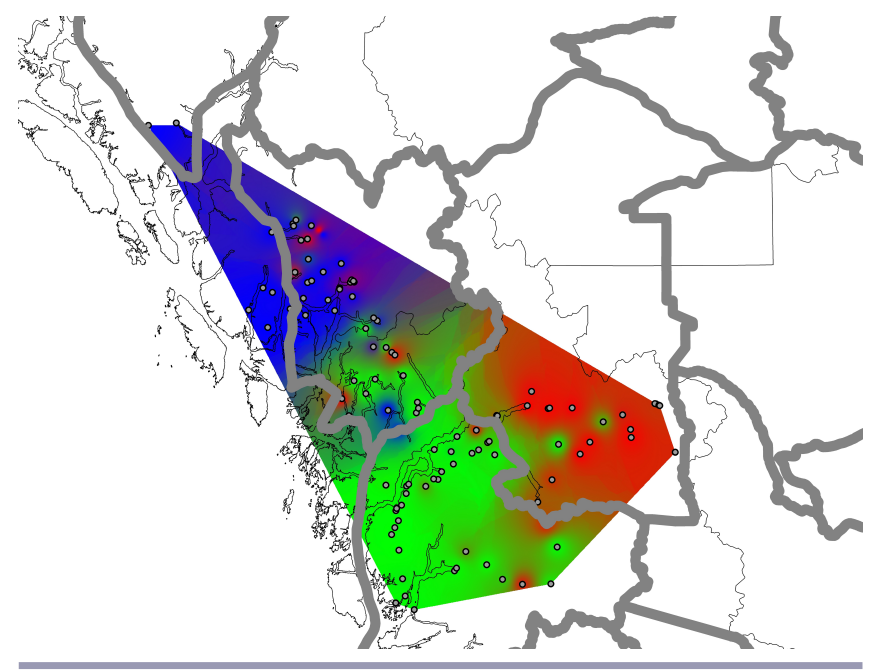

\section{Heterozygosity of grizzly bear groups}

To determine basic population genetic demographics, we determined observed and expected heterozygosity values for the three populations identified by STRUCTURE. The G3 population had observed and expected heterozygosity values similar to those reported for grizzly bears in other areas $\left(\mathrm{H}_{\mathrm{O}}=\right.$ $\left.0.7, \mathrm{H}_{\mathrm{E}}=0.68\right)$. In contrast, the $\mathrm{G} 1\left(\mathrm{H}_{\mathrm{O}}=0.60, \mathrm{H}_{\mathrm{E}}=0.56\right)$ and $\mathrm{G} 2\left(\mathrm{H}_{\mathrm{O}}=0.56, \mathrm{H}_{\mathrm{E}}=0.55\right)$ populations had lower heterozygosity values, similar to those reported for the isolated Selkirk and Yellowstone grizzly bear populations (Table A1.3 in Appendix 1).

\section{Explanatory power of resistance surfaces}

Resistance surfaces did not explain a significant proportion of genetic variation. Within a CA-LRDM framework with geographic distance included as a variable, the archaeological surface explained similar variation in the genetic distance matrix $(23.24 \%)$ to the modern surface $(23.18 \%)$, with water $(P=0.001)$, language boundaries $(P=0.05)$, and geographic distance $(P=$ $0.001)$ identified as significant variables in the archaeological surface. Forestry $(P=0.046)$, waterways $(P=0.001)$, and geographic distance $(P=0.001)$ were significant in the modern surface. Although significant, language boundaries had a low unique contribution $(u=0.002)$ to the variation in the genetic 
Fig. 4. Plots of explained variance $(\%)$ for combinations of all tested variables. (A) Commonality coefficients for the archaeological surface, with $95 \%$ bootstrap confidence intervals $(\mathrm{F} 1=$ language family residuals, $\mathrm{F} 2=$ fish trap residuals, $\mathrm{F} 3=$ midden residuals, F4 = ice and snow residuals, F5 = waterway residuals, F6 = ruggedness residuals). (B) Commonality coefficients for the modern surface, with $95 \%$ bootstrap confidence intervals $(\mathrm{F} 1=$ modern settlement residuals, $\mathrm{F} 2=$ forestry residuals, $\mathrm{F} 3=\mathrm{ice}$ and snow residuals, $\mathrm{F} 4=$ waterway residuals, $\mathrm{F} 5=$ ruggedness residuals).
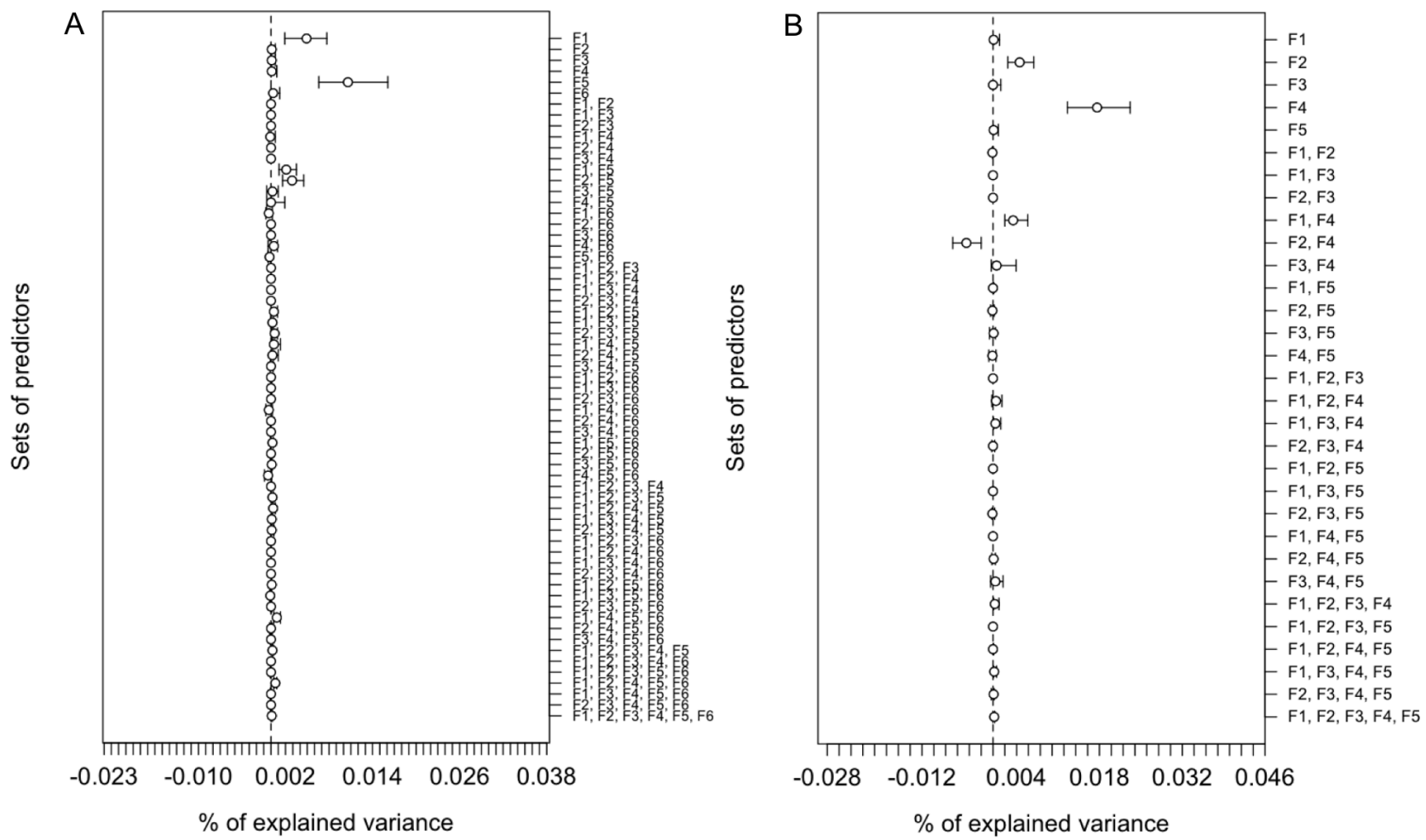

distance matrix. The independent effects of water and geographic distance were difficult to disentangle because of high multicollinearity between these variables $(R=0.901)$. We observed similar multicollinearity between the water and geographic distance variables in the modern surface. Although significant, forestry had both a negative beta weight $(B=-0.053)$ and a low unique contribution $(u=0.003)$. Given the apparent contribution of isolation by distance in this data set, we removed geographic distance from all variables using linear regressions and used Mantel tests to detect correlations among matrices. Finding no substantial correlations $(R>0.7)$, we included all variables in a modern and archaeological surface framework within a CALRDM analysis. With geographic distance removed, the archaeological surface explained only $2.44 \%$ of the variation in STRUCTURE $Q$-values, and the modern surface explained a similarly small percentage $(2.40 \%)$. Language boundaries, however, remained significant $(P=0.001)$ in the archaeological surface in addition to forestry $(P=0.001)$ in the modern surface (Fig. 4). Waterways also remained significant in both modern and archaeological models $(P=0.001)$, but the issues of low unique contributions for language $(u=0.005)$ and forestry $(u=0.005)$, and the negative beta weight of forestry $(B=-0.039$; Fig. A1.6 in Appendix 1) called into question their contribution to genetic structure. Although water continued to be important, it explained a negligible proportion of variation in genetic variation $(1.93 \%$ in archaeological and modern surfaces). To determine if this low explanatory power was due to the parameterization scheme, we tested a model in which all waterways, regardless of width, were assigned maximum resistance. However, waterways continued to have only marginal explanatory power for genetic distances $(0.19 \%$ in archaeological and modern surfaces).

\section{Spatial overlap of grizzly bear genetic groups and Indigenous language families}

Given the finding of significant resistance but very low explanatory power provided by language group boundaries, we found little support for the hypothesis that the relationship between language and bear genetic groupings was mediated by a combination of potential biophysical resistance features present in these border regions. However, the lack of high collinearity $(R$ $>0.7$ ) between language group boundaries and other landscape variables supported the inclusion of language group borders as a unique potential resistance variable. To test the alternate hypothesis that spatial patterns in ecological heterogeneity (i.e., in the distribution of food and other resources) may have resulted in convergent population structure for bears and people, we used ANOSIM and MANOVA to investigate similarities in $Q$-values. We found that bears within the spatial boundaries of distinct language families were both significantly similar to each other 
Fig. 5. Plots of multivariate analysis of variance of STRUCTRE $Q$-values per bear genetic groups (G1, G2, G3) occurring within the spatial boundaries of different Indigenous language families $(\mathrm{A}=$ Tsimshian, $\mathrm{B}=$ Wakashan, $\mathrm{C}=$ Salishan Nuxalk $[$ Lepofsky and Turner 2013]). STRUCTURE $Q$-values belonging to G1 occurred within the spatial boundary of the Tsimshian language family. STRUCTURE $Q$-values belonging to G2 occurred within the spatial boundary of the Wakashan language family. STRUCTURE $Q$-values belonging to G3 occurred within the spatial boundary of the Salishan Nuxalk language family. Boxes represent the interquartile range (middle $50 \%$ of range) with a line corresponding to the median, with whiskers displaying 1.5 box height (limited by maximum and minimum data points) above and below the box.
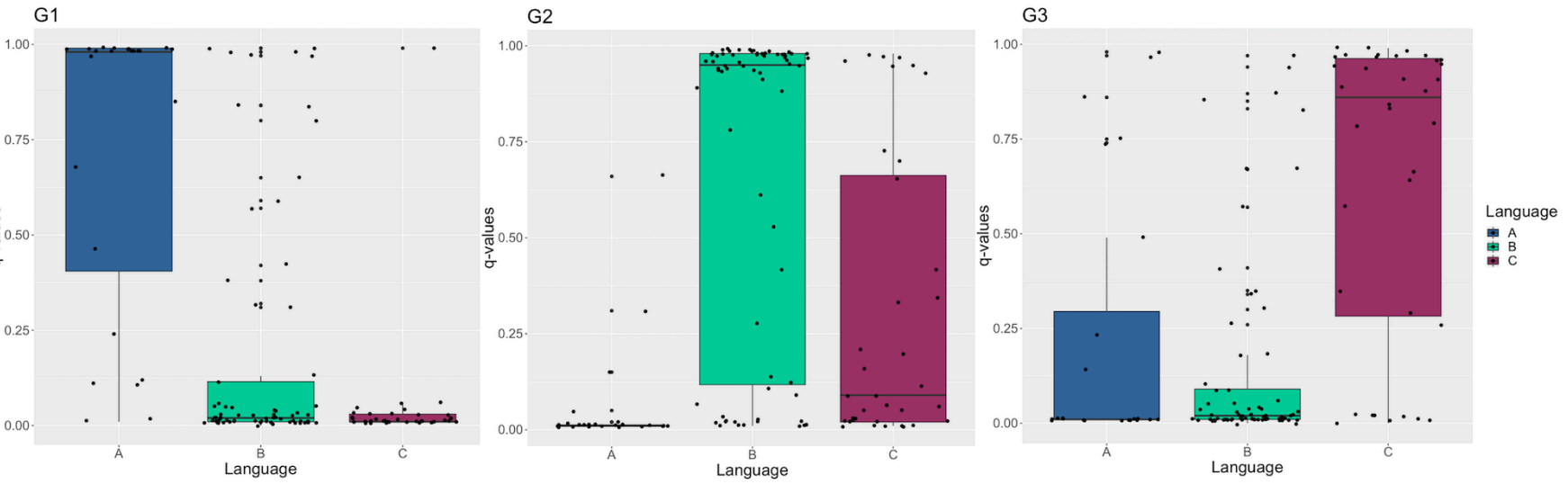

(with some overlap; ANOSIM $R=0.403, P=0.001$ ) and significantly dissimilar to bears located within the geographic areas of other Indigenous language families (MANOVA $P=$ 0.001 ; Fig. 5). Thus, Indigenous language families and bear genetic groups showed significant spatial overlap.

\section{DISCUSSION}

Although it is increasingly apparent that ecological systems reflect long-term human use and cultural influence (e.g., Levis et al. 2017), the legacies of social-ecological systems and biocultural diversity are rarely considered in wildlife landscape genetic analyses. Our finding of spatial convergence between bear genetic groups and Indigenous language families not only offers a new case study to a body of literature describing the relationship between cultural and biological diversity (Maffi 2005, Bridgewater and Rotherham 2019), but also contributes to emerging work on a finer scale of biocultural relationships (i.e., the co-localization of linguistic diversity in humans and genetic diversity in co-occurring wildlife; e.g., Polfus et al. 2016, Schulz et al. 2019, Gagnon et al. 2020). We also showcase here Indigenous-led applied research that provided the first landscape genetics data to inform spatially explicit grizzly bear management on the Central Coast of BC, an area in which First Nations are reasserting their agency to continue managing wildlife and other resources.

We found three clearly distinct grizzly bear genetic groups corroborated by three analysis methods. Analyses using resistance surfaces for both modern and archaeological landscape and anthropogenic variables, however, revealed no significant or biologically meaningful contribution of these variables to this landscape genetic pattern. Of the variables tested, geographic distance played a substantial role, followed by waterways. Although significant, the low explanatory power of both water and Indigenous language family boundaries indicates that their role as resistance factors is slight and likely not biologically relevant for the overall process of bear gene flow in this landscape. Though border areas among language families do not appear to be highly resistant, the finding of spatial genetic structure cooccurring with the spatial distribution of language families suggests that there is not extensive gene flow across these boundary areas. Given this finding, we suggest that the spatial areas encompassed by language families may have experienced a higher degree of human-human interaction within rather than between these regions, as well as long-term coexistence with grizzly bear populations that are similarly structured. These observations appear to contrast with historic examples from less geographically complex environments, where persistent human conflicts between adjacent groups is hypothesized to facilitate associated wildlife refugia along conflict zones (Martin and Szuter 1999, Laliberte and Ripple 2004). Additionally, the lack of substantial collinearity between language family boundaries and the biophysical variables of ruggedness and snow and ice suggests that topography is possibly not the primary driver of linguistic differentiation in this area. Collectively, these patterns and inferences suggest the role of an underlying influence of isolation by distance in grizzly bear genetic structure and the potential contribution of other unexamined landscape, humanrelated, and demographic variables. Specifically, female natalbiased dispersal (Shirane et al. 2018) may contribute to the observed pattern of population structure, although we did not see differences between structural patterns in males and females. Additionally, the pattern might be driven by a response to spatial variation in resource distribution at a smaller spatial scale than we could assess.

The primary limitations of this study include the selection and parameterization of only a handful of potential variables, and the inherent limitations associated with the assumptions of 
parameterization (Zeller et al. 2012). However, we selected variables from relevant literature. Because we used expert opinion guided by relevant literature to parameterize resistance surfaces, we might have under- or overestimated the influence of considered resistance factors facing grizzly bears on the coast (Zeller et al. 2012). Our parameterization scheme, also informed by available literature, is limited. We did conduct a coarse sensitivity analyses with the waterways variable, but the patterns remained unchanged. Additionally, although we used the coarser scale of language family rather than individual Indigenous language dialects, we acknowledge that there remains uncertainty surrounding the precise boundaries and temporal stability of language family boundaries (Thomason and Kaufman 1988). Although we expect some influence of landscape variables on the distribution of Indigenous language families, we acknowledge that socio-cultural and historical factors were likely as or more important in shaping the geographic distribution of language families. Finally, difficulty predicting the temporal lag between the creation and observation of these genetic groups limits the understanding of whether archaeological or modern anthropogenic features do not have an effect on genetic structures or are simply asynchronous. If this uncertain temporal lag is longer than typically expected with microsatellite markers in a highly mobile species (maximum 15 generations; Landguth et al. 2010), postglacial sea-level change and the presence of snow and ice could provide different levels of resistance (e.g., Mackie et al. 2011, 2018). Additionally, this bear genetic structuring pattern, if older than anticipated, may also in part reflect a history of glacial refugia, with genetic groups created through a series of isolation and recolonization events (Waits et al. 1998).

The slightly higher explanatory power of the archaeological surface, the co-localization of bear genetic groups with longstanding Indigenous language families, and the observations of current long-distance bear movements collectively suggest that the grizzly bear genetic structure pattern is at least, in part, historical. Given this inference, the lack of association between human settlement and activities (on both preindustrial and current time frames) and bear genetic structure, despite high archaeological human densities and with year-round intensive landscape use (Hobler et al. 1968, Maxwell et al. 1997, Boyd 1999, Cannon 2003), is somewhat surprising. Other work that considers contemporary human settlement and activities has found that these forces can have pronounced disruptive effects on wildlife, including bears (Proctor et al. 2012, Støen et al. 2015). This absence of a relationship could relate to the previously mentioned asynchronous nature of the grizzly bear genetic structure pattern and archaeological human settlement or the relatively low and variable archaeological survey effort conducted in this region thus far. Alternatively, this result could reflect an Indigenous placebased management model of respect for and reciprocity with bears (Housty et al. 2014) that prioritizes coexistence over dominion, despite considerable resource niche overlap and potentially mediated through avoidance and domestic dog guardians (McKechnie et al. 2020). Such possibilities emphasize the utility of considering a broad suite of landscape parameters, spatial and temporal scales, and human cultural norms toward wildlife when investigating landscape genetic patterns. The assumption of resistance to human activity might be less likely to hold when considering (even dense) human populations of the recent past and varied approaches to coexistence.
The geographic locations of the three observed genetic groups with regard to GBPU designations, the genetic groups of island individuals, and the boundaries of Indigenous language families carry management implications. The finding that the boundary between G1 and G2 was not reflected in GBPU boundaries provides an opportunity for consideration of genetic data in refinements to the designation of GBPUs. Considering that GBPU distinctions are used to set population targets and for landuse planning and priorities (Province of British Columbia 2012), erroneous subdivision of the continuous genetic group with the lowest heterozygosity $(\mathrm{G} 2)$ could lead to incorrect inference regarding the long-term viability of G1 and G2 and the movement and mating patterns of grizzly bears on the landscape. Additionally, our finding that most island individuals $(75 \%)$ belong to the adjacent mainland genetic group supports the inclusion of these recently colonized island populations (Service et al. 2014) within the nearest GBPU. The identification of three genetic groups on the Central Coast suggests that low heterozygosity and population substructuring in grizzly bears are not unique to southern BC. Moreover, owing to the inability of ruggedness to explain the pattern of differentiation, the heights of land between watersheds may not be appropriate for capturing genetic structure on the Central Coast. Future directions to further reassess the delineation of Central Coast GBPUs include the use of whole nuclear and mitochondrial genome markers to assess levels of adaptive differentiation among these groups. Additionally, the co-localization of Indigenous language families and grizzly bear genetic groups emphasizes the need for continued locally led management of this culturally important species, which will likely include population unit delineation by the sovereign Indigenous Nations with the authority and agency to do so.

Co-localization of the spatial extent of Indigenous language families and bear genetic groups implies a potentially similar relationship between each and the landscape, with both producing comparable structural patterns when confronted with the constraints of geographic distance. The strong genetic structure present in grizzly bear populations within the relatively small scale of Central Coast area is consistent with the linguistic diversity present in the area created through the long-term enduring coexistence of distinct languages and communities over time (Beck 2000). The parallel nature of these structures may indicate more than solely similar responses to geographic distance. Specifically, each language family and grizzly bear genetic group may be occupying its own broad resource space with allowance for fine-scale ecological heterogeneity and use by many autonomous Indigenous communities within a single language family (Beck 2000). The degree of either Indigenous language convergence or grizzly bear genetic admixture may be mediated by the intensity of contact among neighboring groups and also the opportunities afforded by the abundant resources on the landscape to support local grizzly bear genetic and human linguistic variation. Although this co-localization does not explicitly show any relationship between grizzly bear and human groupings, it does imply that the same landscape pressures that shaped Indigenous language families, should they be resource or geographically mediated, also could have shaped grizzly bear genetic groups. The spatial convergence of language groupings and grizzly bear genetic groups comes as no surprise to Elders and community members in the territories in which our research 
collaboration occurs, where people and grizzly bears have shared space and resources for millennia. More broadly, this finding contributes to a body of biocultural research that describes the spatial co-occurrence of cultural and linguistic diversity with biological diversity across many different environments and ecosystems (Maffi 2005, Gorenflo et al. 2012). Specifically, our finding of spatial overlap between grizzly bear genetic and human linguistic groups, and the implications of a similar response to biophysical factors, situates this work within scholarship investigating how global patterns of biocultural relationships can manifest at finer scales of genetic and linguistic diversity.

Responses to this article can be read online at: https://www.ecologyandsociety.org/issues/responses. php/12443

\section{Acknowledgments:}

We appreciate and recognize the contribution and collaboration of $>100$ people to the long-term collection of grizzly bear hair samples, with special gratitude extended to our Gitga'at, Haiłzaqv, Kitasool Xai'xais, Wuikinuxv, and Nuxalk leadership and Guardian Watchmen programs, as well as to university project leads Heather Bryan, Kyle Artelle, Megan Adams, Christina Service, and Kate Field. We additionally acknowledge that all samples were collected within the territories of our partner First Nations. LHH was supported in this work by a MITACS Accelerate Fellowship with Raincoast Conservation Foundation and a Habitat Conservation Trust Foundation Seed Grant. AVS was supported by a senior postdoctoral fellowship from Insubria University, Italy. CTD was supported by the Wilburforce Foundation, the SkyeMikko Foundation, the Raincoast Research Chair, and an NSERC Discovery Grant (435683).

\section{Data Availability:}

This research occurred under research protocols with the Gitga'at, Haíłzaqv, Kitasoo/Xai'xais, Wuikinuxv, and Nuxalk Nations. Hair sampling in Conservancies was additionally permitted by BC Parks (Permit 106703). Hair-snagging was approved by the University of Victoria Animal Care Committee (Permit 2012-018). Data (microsatellite loci calls and mean center detection locations) and metadata (code) are deposited in a Zenodo repository (https://doi. org/10.5281/zenodo.4048659). Precise sampling locations cannot be provided given restrictions outlined in protocol agreements with Indigenous governments. Locations of the archaeologically recorded Indigenous settlement and fish trap sites cannot be disclosed due to provincial heritage protection policy and the protocols of Indigenous Nations, but the primary references used to populate the archaeological layer are provided in Table A1.2 in Appendix 1.

\section{LITERATURE CITED}

Adams, M. S., J. Carpenter, J. A. Housty, D. Neasloss, P. C. Paquet, C. Service, J. Walkus, and C. T. Darimont. 2014. Toward increased engagement between academic and indigenous community partners in ecological research. Ecology and Society 19(3):5. https://doi.org/10.5751/ES-06569-190305

Ames, K. M. 2002. Going by boat: the forager-collector continuum at sea. Pages 19-52 in B. Fitzhugh and J. Habu, editors. Beyond foraging and collecting: evolutionary change in huntergatherer settlement systems. Kluwer, Dordrecht, The Netherlands.

Apps, C. D., B. N. McLellan, J. G. Woods, and M. F. Proctor. 2004. Estimating grizzly bear distribution and abundance relative to habitat and human influence. Journal of Wildlife Management 68(1):138-152. https://doi.org/10.2193/0022-541X(2004)068[0138: EGBDAA]2.0.CO;2

Artelle, K. A., S. C. Anderson, A. B. Cooper, P. C. Paquet, J. D. Reynolds, and C. T. Darimont. 2013. Confronting uncertainty in wildlife management: performance of grizzly bear management in British Columbia, Canada. Plos One 8(11):e78041. https://doi. org/10.1371/journal.pone.0078041

Artelle, K. A., M. Zurba, J. Bhattacharyya, D. E. Chan, K. Brown, J. Housty, and F. Moola. 2019. Supporting resurgent Indigenousled governance: a nascent mechanism for just and effective conservation. Biological Conservation 240:108284. https://doi. org/10.1016/j.biocon.2019.108284

Axelsen, J. B., and S. Manrubia. 2014. River density and landscape roughness are universal determinants of linguistic diversity. Proceedings of the Royal Society B: Biological Sciences 281 (1788):20133029. https://doi.org/10.1098/rspb.2014.1179

Balkenhol, N., J. D. Holbrook, D. Onorato, P. Zager, C. White, and L. P. Waits. 2014. A multi-method approach for analyzing hierarchical genetic structures: a case study with cougars Puma concolor. Ecography 37(6):552-563. https://doi.org/10.1111/ j.1600-0587.2013.00462.x

Balloux, F., and N. Lugon-Moulin. 2002. The estimation of population differentiation with microsatellite markers. Molecular Ecology 11(2):155-165. https://doi.org/10.1046/j.0962-1083.2001.01436. $\underline{\mathrm{X}}$

Beck, D. 2000. Grammatical convergence and the genesis of diversity in the Northwest Coast Sprachbund. Anthropological Linguistics 42(2):147-213. [online] URL: https://www.jstor.org/ stable/30028547

Bellemain, E., and P. Taberlet. 2004. Improved noninvasive genotyping method: application to brown bear (Ursus arctos) faeces. Molecular Ecology Notes 4(3):519-522. https://doi. org/10.1111/j.1471-8286.2004.00711.x

Bhattacharyya, J., and S. Slocombe. 2017. Animal agency: wildlife management from a kincentric perspective. Ecosphere 8(10): e01978. https://doi.org/10.1002/ecs2.1978

Boas, F. 1887. The coast tribes of British Columbia. Science 9 (216):288-289. [online] URL: https://www.jstor.org/stable/1763502

Boulanger, J., M. Proctor, S. Himmer, G. Stenhouse, D. Paetkau, and J. Cranston. 2006. An empirical test of DNA mark-recapture sampling strategies for grizzly bears. Ursus 17(2):149-158. https:// doi.org/10.2192/1537-6176(2006)17[149:AETODM]2.0.CO:2 
Boulanger, J., and G. B. Stenhouse. 2014. The impact of roads on the demography of grizzly bears in Alberta. Plos One 9(12): e115535. https://doi.org/10.1371/journal.pone.0115535

Boyd, R. T. 1999. The coming of the spirit of pestilence: introduced infectious diseases and population decline among Northwest Coast Indians, 1774-1874. University of Washington Press, Seattle, Washington, USA.

Bridgewater, P., and I. D. Rotherham. 2019. A critical perspective on the concept of biocultural diversity and its emerging role in nature and heritage conservation. People and Nature 1(3):291-304. https://doi.org/10.1002/pan3.10040

Brown, S. K., J. M. Hull, D. R. Updike, S. R. Fain, and H. B. Ernest. 2009. Black bear population genetics in California: signatures of population structure, competitive release, and historical translocation. Journal of Mammalogy 90(5):1066-1074. https://doi.org/10.1644/08-MAMM-A-193.1

Cannon, A. 1991. The economic prehistory of Namu: patterns in vertebrate fauna. Archaeology Press, Simon Fraser University, Burnaby, Canada. [online] URL: http://archpress.lib.sfu.ca/ index.php/archpress/catalog/book/67

Cannon, A. 2003. Long-term continuity in central northwest coast settlement patterns. Pages 1-12 in R. L. Carlson, editor. Archaeology of coastal British Columbia: essays in honour of Professor Phillip M. Hobler. Archaeology Press, Simon Fraser University, Burnaby, Canada. [online] URL: http://archpress.lib. sfu.ca/index.php/archpress/catalog/book/41

Chiocchini, F., C. Mattioni, P. Pollegioni, I. Lusini, M. A. Martín, M. Cherubini, M. Lauteri, and F. Villani. 2016. Mapping the genetic diversity of Castanea sativa: exploiting spatial analysis for biogeography and conservation studies. Journal of Geographic Information System 8(2):248. http://dx.doi.org/10.4236/jgis.2016.82022

Ciarniello, L. M., M. S. Boyce, D. R. Seip, and D. C. Heard. 2007. Grizzly bear habitat selection is scale dependent. Ecological Applications 17(5):1424-1440. https://doi.org/10.1890/06-1100.1

Clark, D. A., and D. S. Slocombe. 2009. Slocombe. 2009. Respect for grizzly bear: an Aboriginal approach for co-existence and resilience. Ecology and Society 14(1):42. https://doi.org/10.5751/ ES-02892-140142

Codding, B. F., and T. L. Jones. 2013. Environmental productivity predicts migration, demographic, and linguistic patterns in prehistoric California. Proceedings of the National Academy of Sciences 110(36):14569-14573. https://doi.org/10.1073/pnas.1302008110

Collins, G. H., S. D. Kovach, and M. T. Hinkes. 2005. Home range and movements of female brown bears in southwestern Alaska. Ursus 16(2):181-189. https://doi.org/10.2192/1537-6176(2005) 016[0181:HRAMOF]2.0.CO;2

Creanza, N., M. Ruhlen, T. J. Pemberton, N. A. Rosenberg, M. W. Feldman, and S. Ramachandran. 2015. A comparison of worldwide phonemic and genetic variation in human populations. Proceedings of the National Academy of Sciences 112 (5):1265-1272. https://doi.org/10.1073/pnas.1424033112

Earl, D. A., and B. M. vonHoldt. 2012. Structure Harvester: a website and program for visualizing STRUCTURE output and implementing the Evanno method. Conservation Genetics Resources 4:359-361. https://doi.org/10.1007/s12686-011-9548-7

Embleton, S. M. 1985. Lexicostatistics applied to the Germanic, Romance, and Wakashan families. Word 36(1):37-60. https://doi. org/10.1080/00437956.1985.11435862

Ennis, S., and T. F. Gallagher. 1994. A PCR-based sexdetermination assay in cattle based on the bovine amelogenin locus. Animal Genetics 25(6):425-427. https://doi.org/10.1111/ j.1365-2052.1994.tb00533.x

Epps, C. W., P. J. Palsbøll, J. D. Wehausen, G. K. Roderick, R. R. Ramey II, and D. R. McCullough. 2005. Highways block gene flow and cause a rapid decline in genetic diversity of desert bighorn sheep. Ecology Letters 8(10):1029-1038. https://doi. org/10.1111/j.1461-0248.2005.00804.X

Epps, C. W., S. K. Wasser, J. L. Keim, B. M. Mutayoba, and J. S. Brashares. 2013. Quantifying past and present connectivity illuminates a rapidly changing landscape for the African elephant. Molecular Ecology 22(6):1574-1588. https://doi.org/10.1111/ $\underline{\text { mec. } 12198}$

Evanno, G., S. Regnaut, and J. Goudet. 2005. Detecting the number of clusters of individuals using the software STRUCTURE: a simulation study. Molecular Ecology 14 (8):2611-2620. https://doi.org/10.1111/j.1365-294X.2005.02553. $\underline{\mathrm{X}}$

First Peoples' Culture Council of British Columbia. 2020. First Peoples' map of B.C. First Peoples' Culture Council of British Columbia, Brentwood Bay, Canada. [online] URL: https://maps. fpcc.cal

Frantz, A. C., S. Bertouille, M. C. Eloy, A. Licoppe, F. Chaumont, and M. C. Flamand. 2012. Comparative landscape genetic analyses show a Belgian motorway to be a gene flow barrier for red deer (Cervus elaphus), but not wild boars (Sus scrofa). Molecular Ecology 21(14):3445-3457. https://doi.org/10.1111/ j.1365-294X.2012.05623.X

Frantz, A. C., L. C. Pope, T. R. Etherington, G. J. Wilson, and T. Burke. 2010. Using isolation-by-distance-based approaches to assess the barrier effect of linear landscape elements on badger (Meles meles) dispersal. Molecular Ecology 19(8):1663-1674. https://doi.org/10.1111/j.1365-294X.2010.04605.x

Fredholm, M., and A. K. Winterø. 1995. Variation of short tandem repeats within and between species belonging to the Canidae family. Mammalian Genome 6(1):11-18. https://doi. org/10.1007/BF00350887

Gagnon, C. A., S. Hamel, D. E. Russell, T. Powell, J. Andre, M. Y. Svoboda, and D. Berteaux. 2020. Merging Indigenous and scientific knowledge links climate with the growth of a large migratory caribou population. Journal of Applied Ecology 57 (9):1644-1655. https://doi.org/10.1111/1365-2664.13558

Geospatial Data Downloads. 2018. General BC. MapPlace 1. Province of British Columbia, Victoria, Canada. [online] URL: https://www2.gov.bc.ca/gov/content/industry/mineral-explorationmining/british-columbia-geological-survey/mapplace/mapplace1 \#misc 
Gorenflo, L. J., S. Romaine, R. A. Mittermeier, and K. WalkerPainemilla. 2012. Co-occurrence of linguistic and biological diversity in biodiversity hotspots and high biodiversity wilderness areas. Proceedings of the National Academy of Sciences 109 (21):8032-8037. https://doi.org/10.1073/pnas.1117511109

Government of Canada. 2015. Canadian land cover, circa 2000 (vector) - geobase series, 1999-2005. [database]. Natural Resources Canada, Ottawa, Canada. [online] URL: https://open. canada.ca/data/en/dataset/97126362-5a85-4fe0-9dc2-915464cfdbb7

Groffman, P. M., C. Stylinski, M. C. Nisbet, C. M. Duarte, R. Jordan, A. Burgin, M. A. Previtali, and J. Coloso. 2010. Restarting the conversation: challenges at the interface between ecology and society. Frontiers in Ecology and the Environment 8(6):284-291. https://doi.org/10.1890/090160

Guillot, G., F. Mortier, and A. Estoup. 2005. Geneland: a computer package for landscape genetics. Molecular Ecology Notes 5(3):712-715. https://doi.org/10.1111/j.1471-8286.2005.01031. $\underline{\mathrm{x}}$

Gustas, R., and K. Supernant. 2019. Coastal migration into the Americas and least cost path analysis. Journal of Anthropological Archaeology 54:192-206. https://doi.org/10.1016/j.jaa.2019.04.006

Harris, C. 1994. Voices of disaster: smallpox around the Strait of Georgia in 1782. Ethnohistory 41(4):591-626. https://doi. $\underline{\text { org/10.2307/482767 }}$

Harris, L. N., and E. B. Taylor. 2010. Pleistocene glaciations and contemporary genetic diversity in a Beringian fish, the broad whitefish, Coregonus nasus (Pallas): inferences from microsatellite DNA variation. Journal of Evolutionary Biology 23(1):72-86. https://doi.org/10.1111/j.1420-9101.2009.01858.x

Hartmann, S. A., K. Steyer, R. H. S. Kraus, G. Segelbacher, and C. Nowak. 2013. Potential barriers to gene flow in the endangered European wildcat (Felis silvestris). Conservation Genetics 14 (2):413-426. https://doi.org/10.1007/s10592-013-0468-9

Hermosilla, T., M. A. Wulder, J. C. White, N. C. Coops, and G. W. Hobart. 2018. Disturbance-informed annual land cover classification maps of Canada's forested ecosystems for a 29-year Landsat time series. Canadian Journal of Remote Sensing 44 (1):67-87. https://doi.org/10.1080/07038992.2018.1437719

Hobler, P. M. 1968. An archaeological survey in the Ocean Falls Bella Coola area. Permit report 1968-8. On file with the Culture Library, Ministry of Small Business, Tourism and Culture, Victoria, Canada.

Holzhauer, S. I. J., K. Ekschmitt, A.-C. Sander, J. Dauber, and V. Wolters. 2006. Effect of historic landscape change on the genetic structure of the bush-cricket Metrioptera roeseli. Landscape Ecology 21(6):891-899. https://doi.org/10.1007/s10980-005-0438-9

Honkola, T., K. Ruokolainen, K. J. J. Syrjänen, U.-P. Leino, I. Tammi, N. Wahlberg, and O. Vesakoski. 2018. Evolution within a language: environmental differences contribute to divergence of dialect groups. BMC Evolutionary Biology 18:132. https://doi. org/10.1186/s12862-018-1238-6

Housty, W. G., A. Noson, G. W. Scoville, J. Boulanger, R. M. Jeo, C. T. Darimont, and C. E. Filardi. 2014. Grizzly bear monitoring by the Heiltsuk people as a crucible for First Nation conservation practice. Ecology and Society 19(2):70. https://doi.org/10.5751/ ES-06668-190270

Jombart, T. 2008. adegenet: a $\mathrm{R}$ package for the multivariate analysis of genetic markers. Bioinformatics 24(11):1403-1405. https://doi.org/10.1093/bioinformatics/btn129

Kamath, P. L., M. A. Haroldson, G. Luikart, D. Paetkau, C. Whitman, and F. T. van Manen. 2015. Multiple estimates of effective population size for monitoring a long-lived vertebrate: an application to Yellowstone grizzly bears. Molecular Ecology 24(22):5507-5521. https://doi.org/10.1111/mec.13398

Kitahara, E., Y. Isagi, Y. Ishibashi, and T. Saitoh. 2000. Polymorphic microsatellite DNA markers in the Asiatic black bear Ursus thibetanus. Molecular Ecology 9(10):1661-1662. https://doi.org/10.1046/j.1365-294x.2000.01030.x

Laliberte, A. S., and W. J. Ripple. 2004. Range contractions of North American carnivores and ungulates. Bioscience 54 (2):123-138. https://doi.org/10.1641/0006-3568(2004)054[0123: RCONAC]2.0.CO;2

Landguth, E. L., S. A. Cushman, M. K. Schwartz, K. S. McKelvey, M. Murphy, and G. Luikart. 2010. Quantifying the lag time to detect barriers in landscape genetics. Molecular Ecology 19(19):4179-4191. https://doi.org/10.1111/j.1365-294X.2010.04808. $\underline{\mathrm{X}}$

Lepofsky, D., and N. J. Turner. 2013. Introduction to ethnobotany in British Columbia: plants and people in a changing world. $B C$ Studies 179:9-12.

Levis, C., F. R. C. Costa, F. Bongers, M. Peña-Claros, C. R. Clement, A. B. Junqueira, E. G. Neves, E. K. Tamanaha, F. O. G. Figueiredo, R. P. Salomão, C. V. Castilho, W. E. Magnusson, O. L. Phillips, J. E. Guevara, D. Sabatier, J.-F. Molino, D. Cárdenas López, A. M. Mendoza, N. C. A. Pitman, A. Duque, P. Núñez Vargas, C. E. Zartman, R. Vasquez, A. Andrade, J. L. Camargo, T. R. Feldpausch, S. G. W. Laurance, W. F. Laurance, T. J. Killeen, H. E. Mendonça Nascimento, J. C. Montero, B. Mostacedo, I. L. Amaral, I. C. Guimarães Vieira, R. Brienen, H. Castellanos, J. Terborgh, M. de Jesus Veiga Carim, J. R. da Silva Guimarães, L. de Souza Coelho, F. D. de Almeida Matos, F. Wittmann, H. F. Mogollón, G. Damasco, N. Dávila, R. GarcíaVillacorta, E. N. H. Coronado, T. Emilio, D. de Andrade Lima Filho, J. Schietti, P. Souza, N. Targhetta, J. A. Comiskey, B. S. Marimon, B.-H. Marimon Jr., D. Neill, A. Alonso, L. Arroyo, F. A. Carvalho, F. C. de Souza, F. Dallmeier, M. P. Pansonato, J. F. Duivenvoorden, P. V. A. Fine, P. R. Stevenson, A. AraujoMurakami, G. A. Aymard C., C. Baraloto, D. D. do Amaral, J. Engel, T. W. Henkel, P. Maas, P. Petronelli, J. D. Cardenas Revilla, J. Stropp, D. Daly, R. Gribel, M. Ríos Paredes, M. Silveira, R. Thomas-Caesar, T. R. Baker, N. F. da Silva, L. V. Ferreira, C. A. Peres, M. R. Silman, C. Cerón, F. C. Valverde, A. Di Fiore, E. M. Jimenez, M. C. Peñuela Mora, M. Toledo, E. M. Barbosa, L. C. de Matos Bonates, N. C. Arboleda, E. de Sousa Farias, A. Fuentes, J.-L. Guillaumet, P. Møller Jørgensen, Y. Malhi, I. P. de Andrade Miranda, J. F. Phillips, A. Prieto, A. Rudas, A. R. Ruschel, N. Silva, P. von Hildebrand, V. A. Vos, E. L. Zent, S. Zent, B. B. L. Cintra, M. T. Nascimento, A. A. Oliveira, H. Ramirez-Angulo, J. F. Ramos, G. Rivas, J. Schöngart, R. Sierra, M. Tirado, G. van 
der Heijden, E. V. Torre, O. Wang, K. R. Young, C. Baider, A. Cano, W. Farfan-Rios, C. Ferreira, B. Hoffman, C. Mendoza, I. Mesones, A. Torres-Lezama, M. N. U. Medina, T. R. van Andel, D. Villarroel, R. Zagt, M. N. Alexiades, H. Balslev, K. GarciaCabrera, T. Gonzales, L. Hernandez, I. HuamantupaChuquimaco, A. G. Manzatto, W. Milliken, W. P. Cuenca, S. Pansini, D. Pauletto, F. R. Arevalo, N. F. Costa Reis, A. F. Sampaio, L. E. Urrego Giraldo, E. H. Valderrama Sandoval, L. Valenzuela Gamarra, C. I. A. Vela, and H. ter Steege. 2017. Persistent effects of pre-Columbian plant domestication on Amazonian forest composition. Science 355(6328):925-931. https://doi.org/10.1126/science.aal0157

Lewis, T. M., S. Pyare, and K. J. Hundertmark. 2015. Contemporary genetic structure of brown bears (Ursus arctos) in a recently deglaciated landscape. Journal of Biogeography 42 (9):1701-1713. https://doi.org/10.1111/jbi.12524

Mackie, Q., D. Fedje, and D. McLaren. 2018. Archaeology and sea level change on the British Columbia coast. Canadian Journal of Archaeology 42(1):74-91.

Mackie, Q., D. Fedje, D. McLaren, N. Smith, and I. McKechnie. 2011. Early environments and archaeology of coastal British Columbia. Pages 51-103 in N. F. Bicho, J. A. Haws, and L. G. Davis, editors. Trekking the shore: changing coastlines and the antiquity of coastal settlement. Springer, New York, New York, USA. https://doi.org/10.1007/978-1-4419-8219-3 3

Maffi, L. 2005. Linguistic, cultural, and biological diversity. Annual Review of Anthropology 34:599-617. https://doi. org/10.1146/annurev.anthro.34.081804.120437

Manne, L. L. 2002. Nothing has yet lasted forever: current and threatened levels of biological and cultural diversity. Evolutionary Ecology Research 5:517-527. [online] URL: http://www. evolutionary-ecology.com/abstracts/v05/1497.html

Martin, P. S., and C. R. Szuter. 1999. War zones and game sinks in Lewis and Clark's West. Conservation Biology 13(1):36-45. https://doi.org/10.1046/j.1523-1739.1999.97417.x

Maxwell, J., D. McLaren, M. Eldridge, R. Chattan, and T. Hoffman. 1997. Heiltsuk traditional territory archaeological resource overview. Final Report Volume 1, Permit 1995-266. On file with the Culture Library of the Ministry of Small Business, Tourism, and Culture, Victoria, Canada.

McKechnie, I., M. L. Moss, and S. J. Crockford. 2020. Domestic dogs and wild canids on the northwest coast of North America: animal husbandry in a region without agriculture? Journal of Anthropological Archaeology 60:101209. https://doi.org/10.1016/ j.jaa.2020.101209

McLaren, D., D. Fedje, Q. Mackie, L. G. Davis, J. Erlandson, A. Gauvreau, and C. Vogelaar. 2020. Late Pleistocene archaeological discovery models on the Pacific coast of North America. PaleoAmerica 6(1):43-63. https://doi.org/10.1080/20555563.2019.1670512

McLaren, D., F. Rahemtulla, Gitla (E. White), and D. Fedje. 2015. Prerogatives, sea level, and the strength of persistent places: archaeological evidence for long-term occupation of the central coast of British Columbia. BC Studies 187:155-191. https://doi. org/10.14288/bcs.v0i187.186161
McLaren, D., R. J. Wigen, Q. Mackie, and D. W. Fedje. 2005. Bear hunting at the Pleistocene/Holocene transition on the northern northwest coast of North America. Canadian Zooarchaeology 22:3-29. [online] URL: https://journals.uvic.ca/ index.php/zooarchaeology/article/view/5741

McLellan, M. L., B. N. McLellan, R. Sollmann, C. T. Lamb, C. D. Apps, and H. U. Wittmer. 2019. Divergent population trends following the cessation of legal grizzly bear hunting in southwestern British Columbia, Canada. Biological Conservation 233:247-254. https://doi.org/10.1016/j.biocon.2019.02.021

McRae, B. H., B. G. Dickson, T. H. Keitt, and V. B. Shah. $2008 a$. Using circuit theory to model connectivity in ecology, evolution, and conservation. Ecology 89(10):2712-2724. https://doi. org/10.1890/07-1861.1

McRae, B., V. B. Shah, and T. Mohapatra. 2008b. Circuitscape version 4.0.5. The Nature Conservancy, Fort Collins, Colorado, USA. [online] URL: https://github.com/Circuitscape/Circuitscape. pyl

Meilleur, H. 2002. A pour of rain: stories from a west coast fort. Reprint. Raincoast Books, Victoria, Canada.

Meirmans, P. G., and P. W. Hedrick. 2011. Assessing population structure: $F_{\mathrm{ST}}$ and related measures. Molecular Ecology Resources 11(1):5-18. https://doi.org/10.1111/j.1755-0998.2010.02927.x

Moore, J. L., L. Manne, T. Brooks, N. D. Burgess, R. Davies, C. Rahbek, P. Williams, and A. Balmford. 2002. The distribution of cultural and biological diversity in Africa. Proceedings of the Royal Society of London B: Biological Sciences 269 (1501):1645-1653. https://doi.org/10.1098/rspb.2002.2075

Muñoz-Fuentes, V., C. T. Darimont, R. K. Wayne, P. C. Paquet, and J. A. Leonard. 2009. Ecological factors drive differentiation in wolves from British Columbia. Journal of Biogeography 36 (8):1516-1531.https://doi.org/10.1111/j.1365-2699.2008.02067.x

Nichols, J. 1992. Linguistic diversity in space and time. University of Chicago Press, Chicago, Illinois, USA. https://doi.org/10.7208/ chicago/9780226580593.001.0001

Oleksa, A., I. J. Chybicki, M. C. Larsson, G. P. Svensson, and R. Gawroński. 2015. Rural avenues as dispersal corridors for the vulnerable saproxylic beetle Elater ferrugineus in a fragmented agricultural landscape. Journal of Insect Conservation 19 (3):567-580. https://doi.org/10.1007/s10841-015-9778-1

Paetkau, D., W. Calvert, I. Stirling, and C. Strobeck. 1995. Microsatellite analysis of population structure in Canadian polar bears. Molecular Ecology 4(3):347-354. https://doi.org/10.1111/ j.1365-294X.1995.tb00227.x

Paetkau, D., G. F. Shields, and C. Strobeck. 1998a. Gene flow between insular, coastal and interior populations of brown bears in Alaska. Molecular Ecology 7(10):1283-1292. https://doi. org/10.1046/j.1365-294x.1998.00440.x

Paetkau, D., L. P. Waits, P. L. Clarkson, L. Craighead, E. Vyse, R. Ward, and C. Strobeck. 1998b. Variation in genetic diversity across the range of North American brown bears. Conservation Biology 12(2):418-429. https://doi.org/10.1111/j.1523-1739.1998.96457. $\underline{\mathrm{X}}$ 
Polfus, J. L., M. Manseau, D. Simmons, M. Neyelle, W. Bayha, F. Andrew, L. Andrew, C. F. C. Klütsch, K. Rice, and P. Wilson. 2016. Leghágots'enetę (learning together): the importance of Indigenous perspectives in the identification of biological variation. Ecology and Society 21(2):18. http://dx.doi. org/10.5751/ES-08284-210218

Porras-Hurtado, L., Y. Ruiz, C. Santos, C. Phillips, Á. Carracedo, and M. V. Lareu. 2013. An overview of STRUCTURE: applications, parameter settings, and supporting software. Frontiers in Genetics 4:98. https://doi.org/10.3389/fgene.2013.00098

Power, M. J., B. F. Codding, A. H. Taylor, T. W. Swetnam, K. E. Magargal, D. W. Bird, and J. F. O'Connnell. 2018. Human fire legacies on ecological landscapes. Frontiers in Earth Science 6:151. https://doi.org/10.3389/feart.2018.00151

Pretty, J. 2011. Interdisciplinary progress in approaches to address social-ecological and ecocultural systems. Environmental Conservation 38(2):127-139. https://doi.org/10.1017/S0376892910000937

Pritchard, J. K., M. Stephens, and P. Donnelly. 2000. Inference of population structure using multilocus genotype data. Genetics 155(2):945-959. [online] URL: https://www.genetics.org/content/155/2/945

Proctor, M. F., B. N. McLellan, G. B. Stenhouse, G. Mowat, C. T. Lamb, and M. S. Boyce. 2020. Effects of roads and motorized human access on grizzly bear populations in British Columbia and Alberta, Canada. Ursus 2019(30e2):16-39. https://doi. org/10.2192/URSUS-D-18-00016.2

Proctor, M. F., D. Paetkau, B. N. McLellan, G. B. Stenhouse, K. C. Kendall, R. D. Mace, W. F. Kasworm, C. Servheen, C. L. Lausen, M. L. Gibeau, W. L. Wakkinen, M. A. Haroldson, G. Mowat, C. D. Apps, L. M. Ciarniello, R. M. R. Barclay, M. S. Boyce, C. C. Schwartz, and C. Strobeck. 2012. Population fragmentation and inter-ecosystem movements of grizzly bears in western Canada and the northern United States. Wildlife Monographs 180(1):1-46. https://doi.org/10.1002/wmon.6

Province of British Columbia. 2012. British Columbia grizzly bear population estimate for 2012. British Columbia Ministry of Forests, Lands and Natural Resource Operations, Victoria, Canada. [online] URL: https://www.env.gov.bc.ca/fw/wildlife/ docs/Grizzly Bear Pop Est Report Final 2012.pdf

Province of British Columbia. 2016. Hectares BC. [database]. Province of British Columbia, Victoria, Canada. [online] URL: https://www.hectaresbc.org/app/habc/HaBC.html

Prunier, J. G., M. Colyn, X. Legendre, K. F. Nimon, and M. C. Flamand. 2015. Multicollinearity in spatial genetics: separating the wheat from the chaff using commonality analyses. Molecular Ecology 24(2):263-283. https://doi.org/10.1111/mec.13029

R Core Team. 2018. R: a language and environment for statistical computing. $\mathrm{R}$ Foundation for Statistical Computing, Vienna, Austria. [online] URL: https://www.R-project.org/

Riley, S. P. D., J. P. Pollinger, R. M. Sauvajot, E. C. York, C. Bromley, T. K. Fuller, and R. K. Wayne. 2006. A southern California freeway is a physical and social barrier to gene flow in carnivores. Molecular Ecology 15(7):1733-1741. https://doi. org/10.1111/j.1365-294X.2006.02907.X
Schulz, C., M. Martín Brañas, C. Núñez Pérez, M. Del Aguila Villacorta, N. Laurie, I. T. Lawson, and K. H. Roucoux. 2019. Peatland and wetland ecosystems in Peruvian Amazonia: Indigenous classifications and perspectives. Ecology and Society 24(2):12. https://doi.org/10.5751/ES-10886-240212

Service, C. N., M. S. Adams, K. A. Artelle, P. Paquet, L. V. Grant, and C. T. Darimont. 2014. Indigenous knowledge and science unite to reveal spatial and temporal dimensions of distributional shift in wildlife of conservation concern. Plos One 9(7):e101595. https://doi.org/10.1371/journal.pone.0101595

Service, C. N., A. W. Bateman, M. S. Adams, K. A. Artelle, T. E. Reimchen, P. C. Paquet, and C. T. Darimont. 2019. Salmonid species diversity predicts salmon consumption by terrestrial wildlife. Journal of Animal Ecology 88(3):392-404. https://doi. org/10.1111/1365-2656.12932

Shirane, Y., M. Shimozuru, M. Yamanaka, H. Tsuruga, S. Hirano, N. Nagano, J. Moriwaki, M. Nakanishi, T. Ishinazaka, T. Nose, S. Kasai, M. Shirayanagi, Y. Masuda, Y. Fujimoto, M. Osada, M. Akaishi, T. Mano, R. Masuda, M. Sashika, and T. Tsubota. 2018. Sex-biased natal dispersal in Hokkaido brown bears revealed through mitochondrial DNA analysis. European Journal of Wildlife Research 64(6):65. https://doi.org/10.1007/s10344-018-1222$\underline{x}$

Smith, B., N. Baron, C. English, H. Galindo, E. Goldman, K. McLeod, M. Miner, and E. Neeley. 2013. COMPASS: navigating the rules of scientific engagement. Plos Biology 11(4):e1001552. https://doi.org/10.1371/journal.pbio.1001552

Smith, E. A. 2001. On the coevolution of cultural, linguistic, and biological diversity. Pages 95-117 in L. Maffi, editor. On biocultural diversity: linking language, knowledge, and the environment. Smithsonian Institute Press, Washington, D.C., USA.

Spear, S. F., and A. Storfer. 2008. Landscape genetic structure of coastal tailed frogs (Ascaphus truei) in protected vs. managed forests. Molecular Ecology 17(21):4642-4656. https://doi. org/10.1111/j.1365-294X.2008.03952.X

Stepp, J. R., H. Castaneda, and S. Cervone. 2005. Mountains and biocultural diversity. Mountain Research and Development 25 (3):223-227. https://doi.org/10.1659/0276-4741(2005)025[0223: MABD]2.0.CO;2

Støen, O.-G., A. Ordiz, A. L. Evans, T. G. Laske, J. Kindberg, O. Fröbert, J. E. Swenson, and J. M. Arnemo. 2015. Physiological evidence for a human-induced landscape of fear in brown bears (Ursus arctos). Physiology and Behavior 152(A):244-248. https:// doi.org/10.1016/j.physbeh.2015.09.030

Swadesh, M. 1951. Diffusional cumulation and archaic residue as historical explanations. Southwestern Journal of Anthropology 7(1):1-21. https://doi.org/10.1086/soutjanth.7.1.3628647

Thomason, S. G., and T. Kaufman. 1988. Language contact, creolization, and genetic linguistics. University of California Press, Berkeley California, USA.

Thompson, L. C., and D. M. Kinkade. 1990. Handbook of North American Indians. Volume 17, languages. Smithsonian Institute Press, Washington D.C., USA. 
Tolmie, W. F., and G. M. Dawson. 1884. Comparative vocabularies of the Indian tribes of British Columbia, with a map illustrating distribution. Dawson Brothers, Montreal, Canada. https://doi. org/10.4095/216124

Waits, L. P., S. L. Talbot, R. H. Ward, and G. F. Shields. 1998. Mitochondrial DNA phylogeography of the North American brown bear and implications for conservation. Conservation Biology 12(2):408-417. https://doi.org/10.1111/j.1523-1739.1998.96351.

\section{$\underline{\mathrm{X}}$}

Wang, J. 2017. The computer program STRUCTURE for assigning individuals to populations: easy to use but easier to misuse. Molecular Ecology Resources 17(5):981-990. https://doi. org/10.1111/1755-0998.12650

Wright, S. 1943. Isolation by distance. Genetics 28(2):114-138. [online] URL: https://www.genetics.org/content/28/2/114

Zeller, K. A., K. McGarigal, and A. R. Whiteley. 2012. Estimating landscape resistance to movement: a review. Landscape Ecology 27(6):777-797. https://doi.org/10.1007/s10980-012-9737-0

Zellmer, A. J., and L. L. Knowles. 2009. Disentangling the effects of historic vs. contemporary landscape structure on population genetic divergence. Molecular Ecology 18(17):3593-3602. https:// doi.org/10.1111/j.1365-294X.2009.04305.X 


\section{Appendix 1.}

\section{METHODS}

\section{DNA extraction and genotyping details}

We prepared hair samples for extraction by selecting 10 guard hairs when available and supplementing with five underfur hairs per missing guard where needed. When no guard hairs were present in a sample, 30 underfur hairs were chosen.

For microsatellite genotyping, we labeled primers with FAM, HEX, HEX, TET, or NED dye groups. We amplified DNA on a MJ Research PTC-100 thermocycler with PCR reagent concentrations optimized for each primer pair (Table A1.1). We utilized a quality control protocol that involved subsampling each sample and removing samples that were poor quality or had three or more alleles at a locus (Paetkau 2003). This protocol has previously resulted in error rates of 0.002-0.005 per locus per sample (Kendall et al. 2009).

The amelogenin locus for sex determination was amplified using $10 \mathrm{pM}$ of each primer (Forward:CAGCCAAACCTCCCTCTGC Reverse:CCCGCTTGGTCTTGTCTGTTGC), 200uM dNTPs, and 0.9 units of Taq polymerase on a MJ Research PTC-100 thermocycler. We distinguished between male and female individuals using gel electrophoresis with female sample producing a single $280 \mathrm{bp}$ fragment and male samples producing a 280 and a $217 \mathrm{bp}$ fragment. To avoid Y allele dropout, we only sexed samples that produced high confidence scores for all other microsatellite loci (Paetkau 2003). This method has previously produced error rates of 0.0007 per locus per sample (Kendall et al. 2009).

\section{Hardy Weinberg proportions}

Deviations from Hardy Weinberg equilibrium (HWE) were investigated with the web-based version of Genepop (Rousset 2008). Identifying deviations is important as they can provide information on population size, gene flow, and the presence of selection (Allendorf et al. 2012). Additionally, HWE is an essential assumption underlying the model-based clustering algorithms performed by STRUCTURE and Geneland (Pritchard et al. 2000, Guillot et al. 2005).

\section{Connectivity and Resistance Estimation with Mantel tests}

Initially, we utilized partial Mantel tests in R (version 3.2.4, 2018) package ecodist to identify individual landscape variables that explained a significant proportion of variation in the genetic distance variable beyond that explained by geographic distance alone.

\section{RESULTS}

\section{Global deviation from HWE found in one genetic group}


We found significant $(\mathrm{p}<0.05)$ heterozygote deficiency at three loci (G10C, $\mathrm{p}=0.017$; G10L, $\mathrm{p}$ $=0.026$; and MSUT2, $\mathrm{p}=0.030$ in population $\mathrm{G} 3, \mathrm{G} 2$, and G1 respectively). We observed significant $(p<0.05)$ heterozygote excess at four loci: G10B $(p=0.028)$ and G10U $(p=0.040)$ in population $\mathrm{G} 1$, and MU59 $(\mathrm{p}=0.023)$ and X145P07 $(\mathrm{p}=0.030)$ in population G3. Using global HWE tests, we did not find any populations with a significant heterozygote deficit, whereas G1 was the only population that showed significant $(p<0.050)$ global deviation from HWE in the form of heterozygote excess $(p=0.015)$. This heterozygote excess suggests that $\mathrm{G} 1$ may be receiving gene flow from other areas or represents the unification of previously separated populations (Allendorf et al. 2012). Though these deviations from HWE can be problematic for the use of STRUCTURE and Geneland, deviation is only globally present in one genetic group and the breaks between groups are confirmed with sPCA, a method that does not require the assumptions of HWE to be met (Jombart 2008).

\section{Initial Mantel tests showed high multicollinearity between variables}

We validated modern and archaeological surfaces separately using partial Mantel tests, which identified only waterways $(p=0.001)$, fish traps $(p=0.010)$, and Indigenous language family boundaries $(p=0.010)$ as being significant beyond the influence of geographic distance. However, we found a high level of multicollinearity between the resulting significant variables (waterways and fish traps (Mantel $\mathrm{R}=0.817$ ), which prohibited the testing of models with all variables simultaneously against the genetic distance matrix using multiple regression of distance matrices (MRM).

Allendorf, F. W., G.H. Luikart, and S.N. Aitken. 2012. Conservation and the Genetics of Populations. Wiley Blackwell.

Guillot, G., F. Mortier, and A. Estoup. 2005. Geneland : A program for landscape genetics. Molecular Ecology Notes. 5: 712-715.

Jombart, T. 2008. adegenet: a R package for the multivariate analysis of genetic markers. Bioinformatics 24(11):1403-1405.

Kendall, K. C., J. B. Stetz, J. Boulanger, A. C. Macleod, D. Paetkau, and G. C. White. 2009. Demography and Genetic Structure of a Recovering Grizzly Bear Population. The Journal of Wildlife Management 73(1):3-16.

Paetkau, D. 2003. An empirical exploration of data quality in DNA-based population inventories. Molecular Ecology 12(6):1375-1387.

Pritchard, J. K., M. Stephens, and P. Donnelly. 2000. Inference of population structure using multilocus genotype data. Genetics 155(2):945-959. 
85 Rousset, F. 2008. genepop'007: a complete re-implementation of the genepop software for

86 Windows and Linux. Molecular Ecology Resources 8(1):103-106.

87 


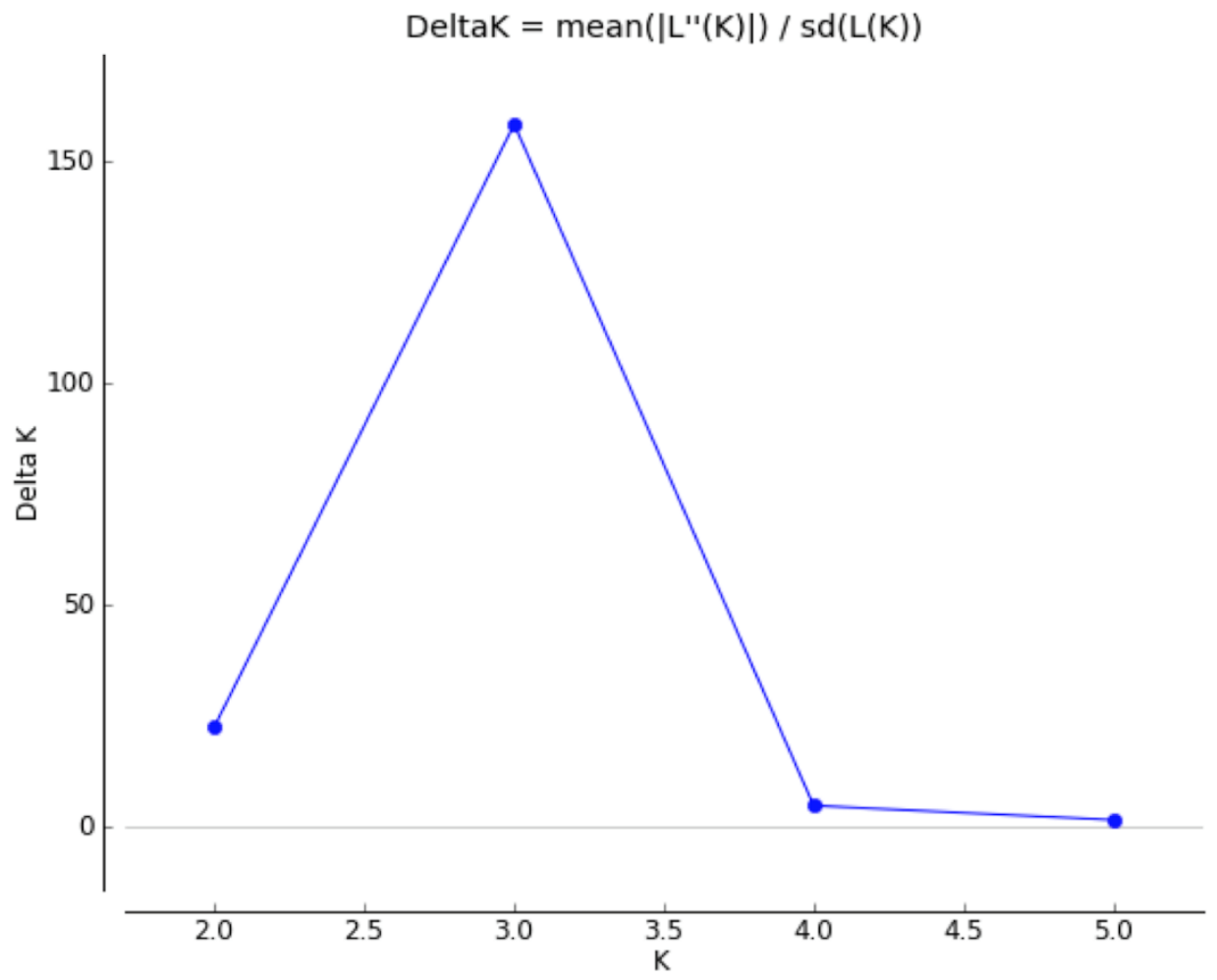

Figure A1.1 Delta $K$ plot identifying the most probable $K$ using the Evanno method as implemented in Structure Harvester for the results of STRUCTURE analysis. 

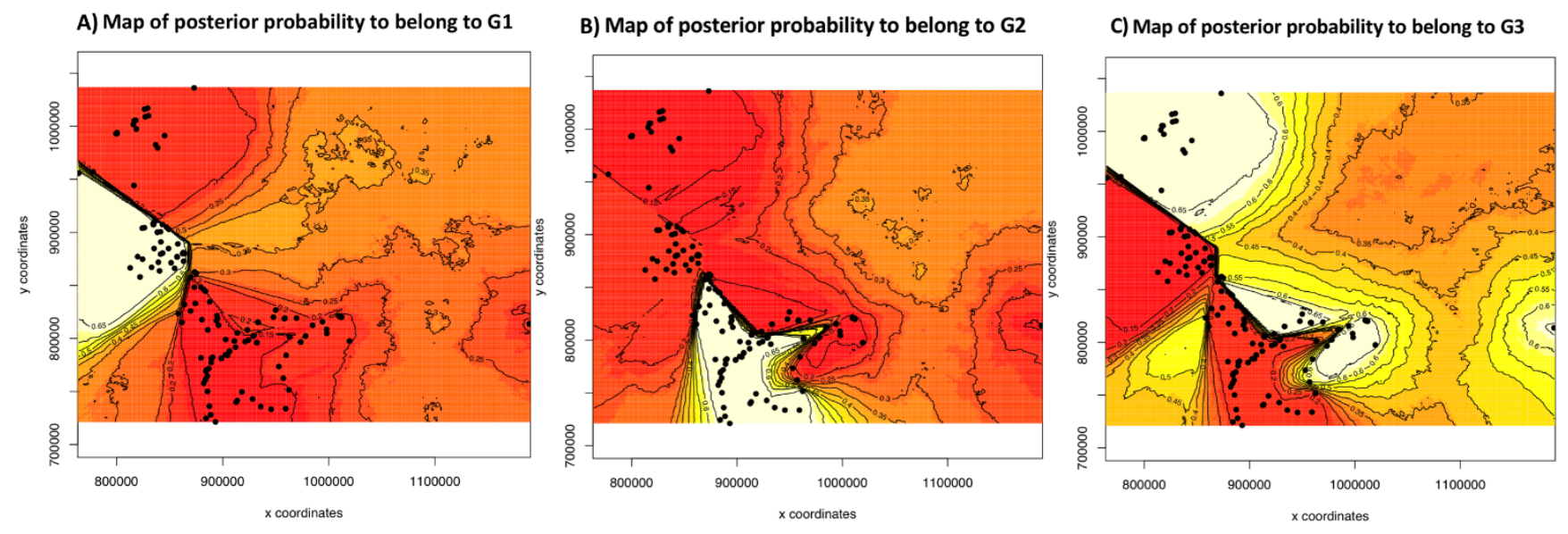

Figure A1.2 Spatial grizzly bear population structure map produced by Bayesian clustering model implemented in Geneland. High population membership is indicated by yellow and cream colors and genetic discontinuities between populations are represented by dense contour lines. A) Spatial output for G1. B) Geneland spatial output for G2.C) Geneland spatial output for G3. 


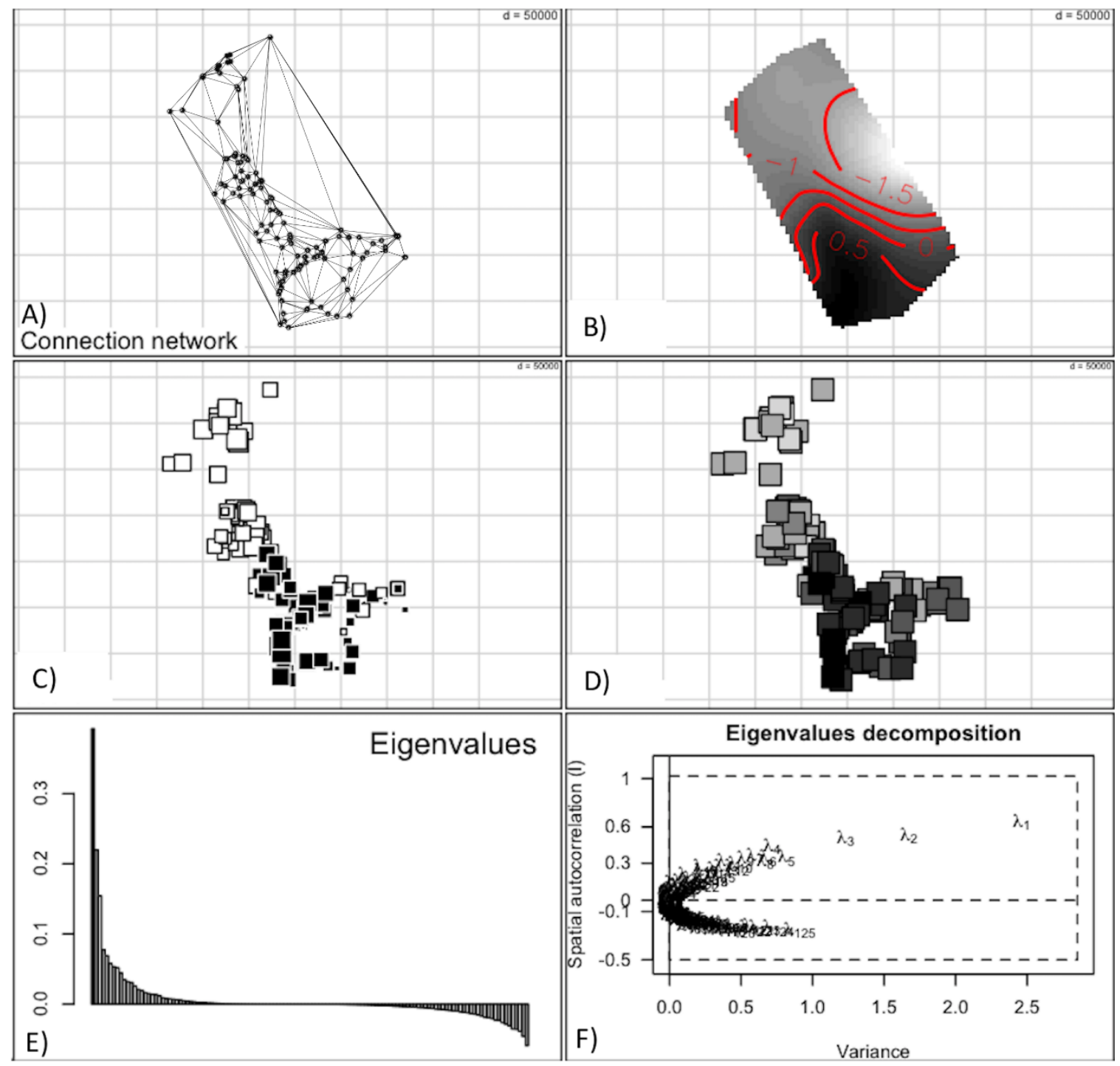

Figure A1.3 Spatial Principal Components Analysis of grizzly bear population structure for male and female bears conducted with a A) Delauney Connection Network and producing B-D) three representations of the first score and E-F) two eigenvalue plots. 


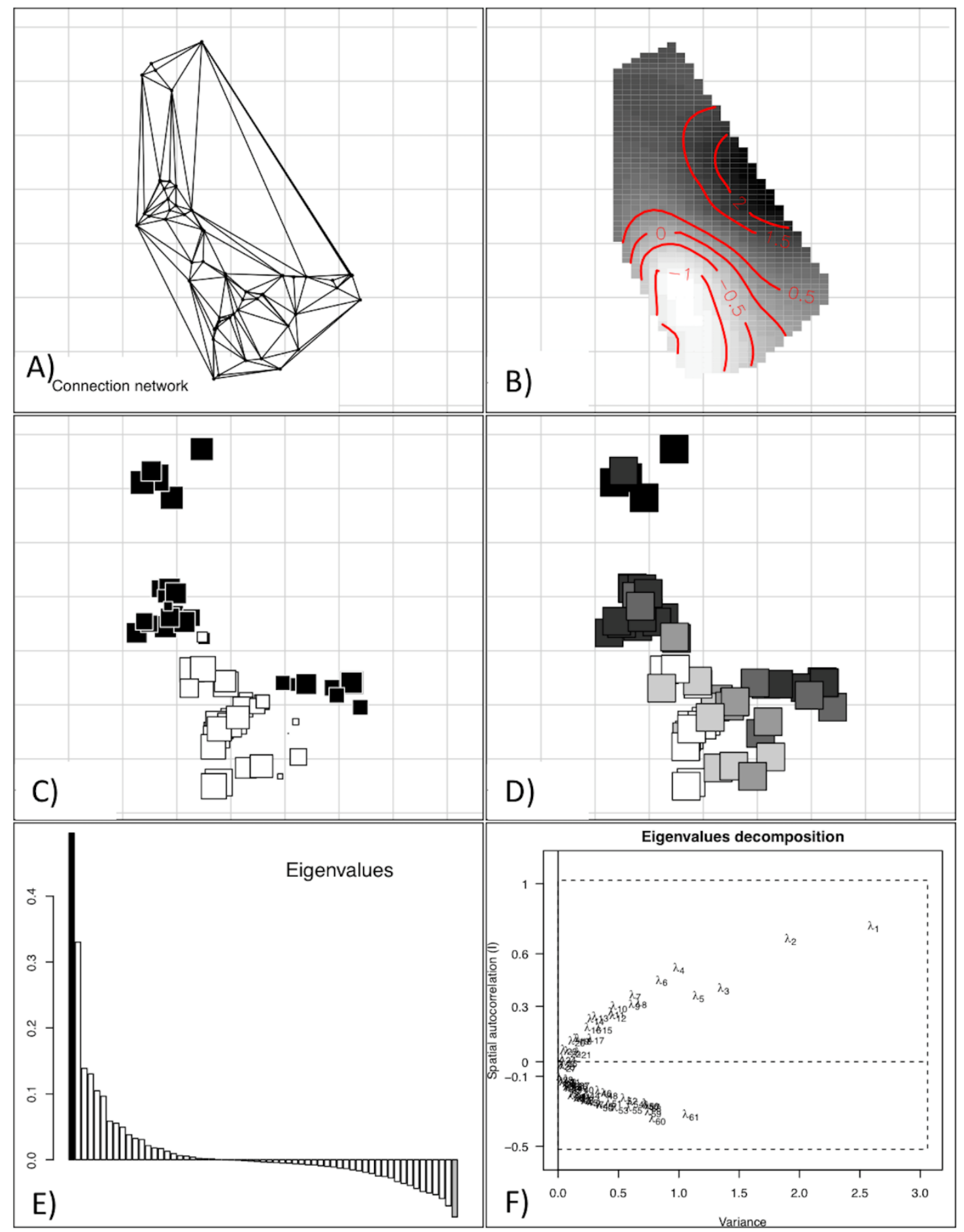

Figure A1.4 Spatial Principal Components Analysis of grizzly bear population structure for female bears conducted with a A) Delauney Connection Network and producing B-D) three representations of the first score and E-F) two eigenvalue plots. 


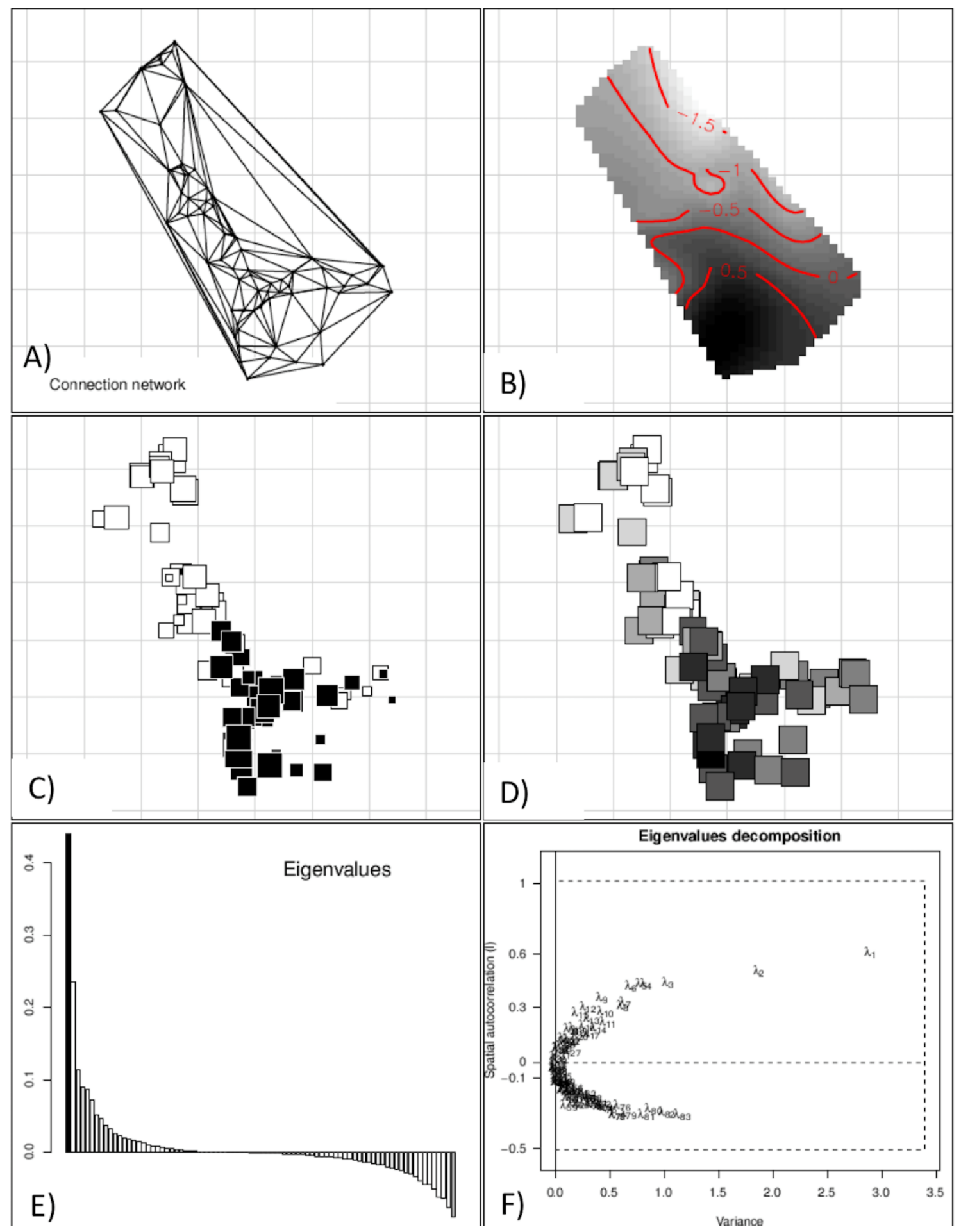

Figure A1.5 Spatial Principal Components Analysis of grizzly bear population structure for male bears conducted with a A) Delauney Connection Network and producing B-D) three representations of the first score and E-F) two eigenvalue plots. 

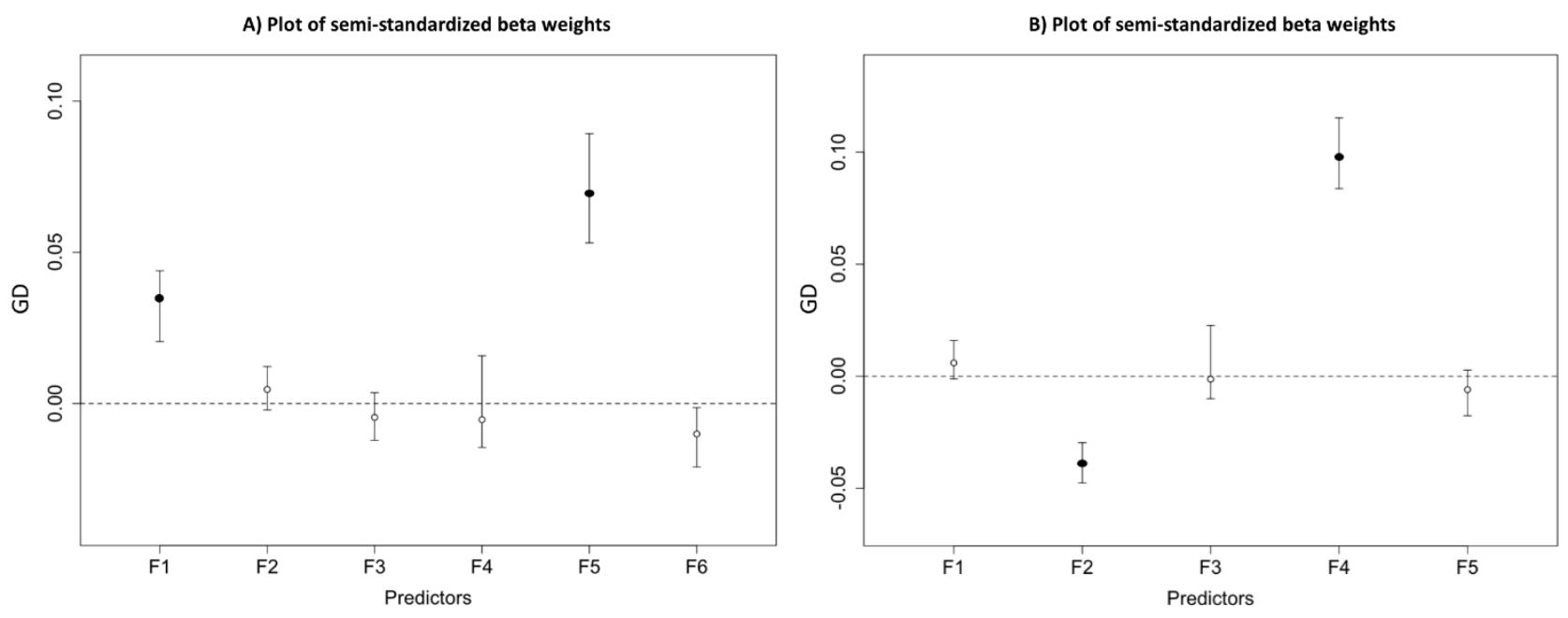

Figure A1.6 Commonality analysis beta weights with filled circles indicating significant beta weights for the A) archaeological surface with $95 \%$ bootstrap confidence intervals. (F1=Language family residuals, F2=Fish trap residuals, F3=Midden residuals, F4=Ice and snow residuals, F5=Waterway residuals, F6=Ruggedness residuals) and B) the modern surface with 95\% bootstrap confidence intervals. (F1 = Modern settlement residuals, F2 $=$ Forestry residuals, F3 = Ice and snow residuals, $\mathrm{F} 4=$ Waterway residuals, F5 $=$ Ruggedness residuals). 
Table A1.1 Microsatellite loci, primer pairs, and PCR reagent concentrations

\begin{tabular}{|c|c|c|c|c|c|}
\hline Locus & Forward primer & Reverse primer & $\begin{array}{c}\text { Primer } \\
\text { concentration } \\
(\mathrm{nM})\end{array}$ & $\begin{array}{c}\mathrm{MgCL}_{2} \\
(\mathrm{mM})\end{array}$ & $\begin{array}{c}\text { Units of } \\
\text { Polymerase } \\
\text { (Taq) }\end{array}$ \\
\hline${\mathrm{G} 1 \mathrm{~A}^{1}}^{1}$ & $\begin{array}{l}\text { GACCCTGCATACTCTCC } \\
\text { TCTGAT }\end{array}$ & $\begin{array}{l}\text { GCACTGTCC'ITGCGTAGA } \\
\text { AGTGAC }\end{array}$ & 160 & 1.9 & 0.5 \\
\hline $\mathrm{G}^{1} \mathrm{D}^{1}$ & $\begin{array}{l}\text { GATCTGTGGGTTTATAG } \\
\text { GTTACA }\end{array}$ & $\begin{array}{l}\text { CTACTCTTCCTACTCTTTA } \\
\text { AGAG }\end{array}$ & 160 & 1.9 & 0.5 \\
\hline $\mathrm{G}^{10 \mathrm{~B}^{1}}$ & $\begin{array}{l}\text { GCCTTTTAATGTTCTGT } \\
\text { TGAATTTG }\end{array}$ & $\begin{array}{l}\text { GACAAATCACAGAAACCT } \\
\text { CCATCC }\end{array}$ & 160 & 1.9 & 0.5 \\
\hline G10C ${ }^{1}$ & $\begin{array}{l}\text { AAAGCAGAAGGCCTTG } \\
\text { ATTTCCTG }\end{array}$ & $\begin{array}{l}\text { GGGGACATAAACACCGA } \\
\text { GACAG }\end{array}$ & 160 & 1.9 & 0.5 \\
\hline $\mathrm{G} 10 \mathrm{~L}^{1}$ & $\begin{array}{l}\text { GTACTGATTTAATTCAC } \\
\text { ATTTCCC }\end{array}$ & $\begin{array}{l}\text { GAAGATACAGAAACCTAC } \\
\text { CCTGC }\end{array}$ & 160 & 1.9 & 0.5 \\
\hline $\mathrm{G} 10 \mathrm{M}^{1}$ & $\begin{array}{l}\text { TTCCCCTCATCGTAGGT } \\
\text { TGTA }\end{array}$ & $\begin{array}{l}\text { GATCATGTGTTTCCAAAT } \\
\text { AAT }\end{array}$ & 160 & 1.9 & 0.5 \\
\hline $\mathrm{G} 10 \mathrm{P}^{1}$ & $\begin{array}{l}\text { AGGAGGAAGAAAGATG } \\
\text { GAAAAC }\end{array}$ & $\begin{array}{l}\text { TCATGTGGGGAAATACTT } \\
\text { CAA }\end{array}$ & 160 & 1.9 & 0.5 \\
\hline G10X ${ }^{1}$ & $\begin{array}{l}\text { CCCTGGTAACCACAAA } \\
\text { TCTCT }\end{array}$ & $\begin{array}{l}\text { TCAGTTATCTGTGAAATC } \\
\text { AAAA }\end{array}$ & 160 & 1.9 & 0.5 \\
\hline $\mathrm{G} 10 \mathrm{~J}^{2}$ & $\begin{array}{l}\text { GATCAGATATTTTCAGC } \\
\text { TTT }\end{array}$ & $\begin{array}{l}\text { AACCCCTCACACTCCACT } \\
\text { TC }\end{array}$ & 253 & 1.9 & 2.4 \\
\hline $\mathrm{G} 10 \mathrm{H}^{2}$ & $\begin{array}{l}\text { CAACAAGAAGACCACT } \\
\text { GTAA }\end{array}$ & $\begin{array}{l}\text { AGAGACCACCAAGTAGG } \\
\text { ATA }\end{array}$ & 227 & 1,9 & 2.0 \\
\hline G10U² & $\begin{array}{l}\text { TGCAGTGTCAGTTGTTA } \\
\text { CCAA }\end{array}$ & $\begin{array}{l}\text { TATTTCCAATGCCCTAAG } \\
\text { TGAT }\end{array}$ & 320 & 2.1 & 3.2 \\
\hline $\begin{array}{l}\text { CXX11 } \\
0^{2}\end{array}$ & $\begin{array}{l}\text { TGCTTTGGGTTAAATCT } \\
\text { AAGCC }\end{array}$ & CCCCAGAGATGTGGCATC & 320 & 2.1 & 3.2 \\
\hline $\begin{array}{l}\text { CXX20 } \\
2\end{array}$ & $\begin{array}{l}\text { AGCAACCCCTCCCATTT } \\
\text { ACT }\end{array}$ & $\begin{array}{l}\text { TTGTCTGAATAGTCCTCT } \\
\text { GCG }\end{array}$ & 187 & 2.1 & 3.2 \\
\hline MU23 $^{3}$ & $\begin{array}{l}\text { GCCTGTGTGCTATTTTA } \\
\text { TCC }\end{array}$ & TTGCTTGCCTAGACCACC & 600 & 2.0 & 0.5 \\
\hline MU50 ${ }^{2}$ & $\begin{array}{l}\text { GGAGGCGTTCTTTCAGT } \\
\text { TGGT }\end{array}$ & $\begin{array}{l}\text { TGGAACAAAACTTAACAC } \\
\text { AAATG }\end{array}$ & 320 & 1.9 & 2.0 \\
\hline MU59² & $\begin{array}{l}\text { GCTGCTTTGGGACATTG } \\
\text { TAA }\end{array}$ & $\begin{array}{l}\text { CAATCAGGCATGGGGAA } \\
\text { GAA }\end{array}$ & 320 & 1.9 & 2.8 \\
\hline MU51 ${ }^{3}$ & $\begin{array}{l}\text { AGCCAGAATCCTAAGA } \\
\text { GACCT }\end{array}$ & $\begin{array}{l}\text { GAAAGGTTAGATGGAAG } \\
\text { AGATG }\end{array}$ & 600 & 2.0 & 0.5 \\
\hline $\mathrm{CPH}^{5}$ & $\begin{array}{l}\text { CAGAGACTGCCACTTT } \\
\text { AAACACAC }\end{array}$ & $\begin{array}{l}\text { AAAGTTCTCAAATACCAT } \\
\text { TGTGTTACA }\end{array}$ & 300 & 59 & 0.6 \\
\hline $\begin{array}{l}144 \mathrm{~A} 0 \\
6^{6}\end{array}$ & $\begin{array}{l}\text { TTTTATGGTTGAGTGCT } \\
\text { ATTCC }\end{array}$ & $\begin{array}{l}\text { GAAATTGGCCACAGTTCC } \\
\text { AT }\end{array}$ & 160 & 1.9 & 0.5 \\
\hline $\begin{array}{l}\text { MSUT } \\
2^{4}\end{array}$ & $\begin{array}{l}\text { AGTGAATCCTAAACAG } \\
\text { GTTA }\end{array}$ & $\begin{array}{l}\text { TAATATGAATATGGTGTG } \\
\text { CT }\end{array}$ & 500 & 1.5 & 0.5 \\
\hline
\end{tabular}




\begin{tabular}{|l|l|l|l|l|l|}
\hline $\begin{array}{l}145 \mathrm{P} 07 \\
6\end{array}$ & $\begin{array}{l}\text { TGGAAAGGTTTGCACT } \\
\text { CTGA }\end{array}$ & $\begin{array}{l}\text { AGCCTCCCCATTTCACAG } \\
\text { AT }\end{array}$ & 160 & 1.9 & 0.5 \\
\hline
\end{tabular}

${ }^{1}$ Paetkau (1995), ${ }^{2}$ Paetkau (1998), ${ }^{3}$ Bellemain and Taberlet (2004), ${ }^{4}$ Kitahara et al. (2000), ${ }^{5}$ Fredholm and Winterø (1995), ${ }^{6}$ Kamath (2015) 
Table A1.2 Primary sources for archaeologically recorded shell middens and fish traps in the study area

\begin{tabular}{|c|c|c|c|}
\hline Site Number & Reference & Shell Midden & Fish Trap \\
\hline FaSx-14 & (Apland 1974) & $\mathrm{X}$ & \\
\hline FaSx-15 & (Apland 1974) & $\mathrm{X}$ & \\
\hline FaSx-5 & (Apland 1974) & & $\mathrm{X}$ \\
\hline FaTa-14 & (Hester 1968) & $\mathrm{X}$ & \\
\hline $\mathrm{FbSr}-4$ & (Bedard 1993) & $\mathrm{X}$ & \\
\hline FbSr-6 & (Bedard 1993) & & $\mathrm{X}$ \\
\hline FbSr-9 & (Dahm and Hobler 1996) & $\mathrm{X}$ & \\
\hline FbSu-1 & (Carlson 1970; Carlson 1971) & $\mathrm{X}$ & \\
\hline $\mathrm{FbSv}-2$ & (Luebbers 1971) & $\mathrm{X}$ & \\
\hline FbSw-3 & (Hobler 1968) & $\mathrm{X}$ & \\
\hline FbSw-6 & (Luebbers 1971) & & $\mathrm{X}$ \\
\hline FbSx-12 & (Apland 1974) & $\mathrm{X}$ & \\
\hline FbSx-2 & (Hester 1968) & & $\mathrm{X}$ \\
\hline FbSx-3 & (Hester 1968) & $\mathrm{X}$ & \\
\hline FbSx-4 & (Hester 1968) & $\mathrm{X}$ & \\
\hline FbSx-6 & (Luebbers 1971) & $\mathrm{X}$ & \\
\hline FbSx-9 & (Carlson 1972) & $\mathrm{X}$ & \\
\hline FbTa-1 & (Hester 1968) & $\mathrm{X}$ & \\
\hline FbTa-10 & (Luebbers 1971) & $\mathrm{X}$ & \\
\hline FbTa-11 & (Luebbers 1971) & & $\mathrm{X}$ \\
\hline FbTa-12 & (Luebbers 1971) & $\mathrm{X}$ & \\
\hline FbTa-13 & (Luebbers 1971) & $\mathrm{X}$ & \\
\hline FbTa-14 & (Luebbers 1971) & & $\mathrm{X}$ \\
\hline FbTa-15 & (Luebbers 1971) & $\mathrm{X}$ & $\mathrm{X}$ \\
\hline FbTa-16 & (Luebbers 1971) & $\mathrm{X}$ & \\
\hline FbTa-17 & (Mitchell 1969) & $\mathrm{X}$ & \\
\hline FbTa-18 & (Luebbers 1971) & & $\mathrm{X}$ \\
\hline FbTa-19 & (Luebbers 1971) & & $\mathrm{X}$ \\
\hline FbTa-21 & (Luebbers 1971) & $\mathrm{X}$ & \\
\hline FbTa-22 & (Luebbers 1971) & $\mathrm{X}$ & \\
\hline FbTa-23 & (Luebbers 1971) & $\mathrm{X}$ & \\
\hline FbTa-25 & (Pomeroy 1980) & $\mathrm{X}$ & \\
\hline FbTa-26 & (Seymour et al. 1980) & $\mathrm{X}$ & \\
\hline FbTa-27 & (Maxwell et al. 1997) & $\mathrm{X}$ & \\
\hline FbTa-28 & (Maxwell et al. 1997) & $\mathrm{X}$ & \\
\hline FbTa-29 & (Maxwell et al. 1997) & $\mathrm{X}$ & \\
\hline FbTa-3 & (Hobler 1977) & $\mathrm{X}$ & $\mathrm{X}$ \\
\hline FbTa-30 & (Maxwell et al. 1997) & $\mathrm{X}$ & \\
\hline FbTa-33 & (Maxwell et al. 1997) & & $\mathrm{X}$ \\
\hline FbTa-34 & (Maxwell et al. 1997) & & $\mathrm{X}$ \\
\hline FbTa-43 & (Maxwell et al. 1997) & $\mathrm{X}$ & \\
\hline FbTa-5 & (Dahm and Hobler 1996) & $\mathrm{X}$ & \\
\hline FbTa-59 & (White 2006; White 2011) & & $\mathrm{X}$ \\
\hline FbTa-6 & (Hester 1969) & $\mathrm{X}$ & \\
\hline FbTa-7 & (Luebbers 1971) & $\mathrm{X}$ & \\
\hline FbTa-8 & (Luebbers 1971) & & $\mathrm{X}$ \\
\hline
\end{tabular}




\begin{tabular}{|c|c|c|c|}
\hline Site Number & Reference & Shell Midden & Fish Trap \\
\hline FbTa-9 & (Luebbers 1971) & $X$ & \\
\hline FbTb-1 & (Hester 1968) & $\mathrm{X}$ & \\
\hline $\mathrm{FbTb}-10$ & (Luebbers 1971) & & $\mathrm{X}$ \\
\hline FbTb-11 & (Luebbers 1971) & & $\mathrm{X}$ \\
\hline $\mathrm{FbTb}-12$ & (Luebbers 1971) & $\mathrm{X}$ & \\
\hline FbTb-13 & (Brown 1989) & & $X$ \\
\hline FbTb-14 & (Luebbers 1971) & & $\mathrm{X}$ \\
\hline FbTb-16 & (Brown 1989) & & $\mathrm{X}$ \\
\hline $\mathrm{FbTb}-17$ & (Luebbers 1971) & $X$ & \\
\hline $\mathrm{FbTb}-18$ & (Luebbers 1971) & $\mathrm{X}$ & \\
\hline FbTb-19 & (Luebbers 1971) & & $\mathrm{X}$ \\
\hline $\mathrm{FbTb}-20$ & (Luebbers 1971) & & $\mathrm{X}$ \\
\hline $\mathrm{FbTb}-21$ & (Brown 1989) & $\mathrm{X}$ & \\
\hline $\mathrm{FbTb}-22$ & (Maxwell et al. 1997) & $\mathrm{X}$ & \\
\hline $\mathrm{FbTb}-23$ & (Maxwell et al. 1997) & $\mathrm{X}$ & \\
\hline $\mathrm{FbTb}-24$ & (Maxwell et al. 1997) & $\mathrm{X}$ & \\
\hline $\mathrm{FbTb}-4$ & (Mitchell 1969; Simonsen 1973) & $\mathrm{X}$ & \\
\hline FbTb-5 & (Simonsen 1992) & $\mathrm{X}$ & \\
\hline FbTb-6 & (Luebbers 1971) & $\mathrm{X}$ & \\
\hline FbTb-7 & (Luebbers 1971) & & $\mathrm{X}$ \\
\hline FbTb-9 & (Luebbers 1971) & & $\mathrm{X}$ \\
\hline FbTc-1 & (Hester 1969) & $\mathrm{X}$ & $\mathrm{X}$ \\
\hline FbTc-10 & (Luebbers 1971) & $\mathrm{X}$ & \\
\hline FbTc-11 & (Luebbers 1971) & $\mathrm{X}$ & \\
\hline FbTc-12 & (Luebbers 1971) & $\mathrm{X}$ & \\
\hline FbTc-13 & (Luebbers 1971) & $\mathrm{X}$ & \\
\hline FbTc-14 & (Luebbers 1971) & & $\mathrm{X}$ \\
\hline FbTc-15 & (Luebbers 1971) & & $\mathrm{X}$ \\
\hline FbTc-16 & (Luebbers 1971) & & $\mathrm{X}$ \\
\hline FbTc-19 & (Maxwell et al. 1997) & & $\mathrm{X}$ \\
\hline FbTc-2 & (Luebbers 1971) & $\mathrm{X}$ & \\
\hline FbTc-20 & (Maxwell et al. 1997) & & $\mathrm{X}$ \\
\hline FbTc-21 & (Maxwell et al. 1997) & & $\mathrm{X}$ \\
\hline FbTc-22 & (Maxwell et al. 1997) & & $\mathrm{X}$ \\
\hline FbTc-29 & (Maxwell et al. 1997) & & $\mathrm{X}$ \\
\hline FbTc-3 & (Luebbers 1971) & $\mathrm{X}$ & \\
\hline FbTc-30 & (Maxwell et al. 1997) & & $\mathrm{X}$ \\
\hline FbTc-4 & (Luebbers 1971) & $\mathrm{X}$ & \\
\hline FbTc-5 & (Luebbers 1971) & $\mathrm{X}$ & \\
\hline FbTc-6 & (Luebbers 1971) & $\mathrm{X}$ & \\
\hline FbTc-7 & (Luebbers 1971) & $\mathrm{X}$ & \\
\hline FbTc-8 & (Luebbers 1971) & $\mathrm{X}$ & \\
\hline FcSt-1 & (Hobler 1968) & $\mathrm{X}$ & \\
\hline FcSt-10 & (Maxwell et al. 1995b) & & $X$ \\
\hline FcSt-12 & (Maxwell et al. 1995b) & $\mathrm{X}$ & \\
\hline FcSt-13 & (Maxwell et al. 1995b) & $\mathrm{X}$ & \\
\hline FcSt-3 & (Hobler 1968; Maxwell et al. 1995b) & $\mathrm{X}$ & \\
\hline FcSt-8 & (Blacklaws 1980) & & $\mathrm{X}$ \\
\hline
\end{tabular}




\begin{tabular}{|c|c|c|c|}
\hline Site Number & Reference & Shell Midden & Fish Trap \\
\hline FcSu-1 & (Hobler 1983) & $\mathrm{X}$ & \\
\hline FcSv-4 & (Hester 1969) & & $\mathrm{X}$ \\
\hline $\mathrm{FcSw}-1$ & (Hester 1968) & & $X$ \\
\hline FcSx-14 & (Luebbers 1971) & & $X$ \\
\hline FcSx-15 & (Luebbers 1971) & & $X$ \\
\hline FcSx-19 & (Apland 1974) & & $\mathrm{X}$ \\
\hline $\mathrm{FcSx}-2$ & (Hester 1969) & & $X$ \\
\hline FcSx-3 & (Hester 1969) & & $X$ \\
\hline FcTa-11 & (Hobler 1977) & & $X$ \\
\hline FcTa-12 & (Hobler 1977) & & $\mathrm{X}$ \\
\hline FcTa-17 & (Maxwell et al. 1997) & $X$ & \\
\hline FcTa-18 & (Maxwell et al. 1997) & & $X$ \\
\hline FcTa-19 & (Maxwell et al. 1997) & $X$ & \\
\hline FcTa-2 & (Luebbers 1971) & & $\mathrm{X}$ \\
\hline FcTa-20 & (Maxwell et al. 1997) & & $X$ \\
\hline FcTa-22 & (Maxwell et al. 1997) & & $\mathrm{X}$ \\
\hline FcTa-3 & (Luebbers 1971) & $\mathrm{X}$ & $\mathrm{X}$ \\
\hline FcTa-5 & (Luebbers 1971) & & $\mathrm{X}$ \\
\hline FcTa-6 & (Luebbers 1971) & & $X$ \\
\hline FcTa-7 & (Luebbers 1971) & & $X$ \\
\hline FcTa-78 & (Engisch et al. 2011) & $\mathrm{X}$ & \\
\hline FcTb-10 & (Maxwell et al. 1995a) & & $\mathrm{X}$ \\
\hline FcTb-2 & (Finnis et al. 1993) & & $\mathrm{X}$ \\
\hline FcTb-3 & (Luebbers 1971) & & $X$ \\
\hline $\mathrm{FcTb}-4$ & (Luebbers 1971) & & $X$ \\
\hline FcTc-2 & (Mitchell 1969) & $\mathrm{X}$ & \\
\hline FcTc-3 & (Luebbers 1971) & $\mathrm{X}$ & \\
\hline FcTc-4 & (Mitchell 1969) & $X$ & \\
\hline FcTc-5 & (Mitchell 1969; Simonsen 1973) & $\mathrm{X}$ & \\
\hline FcTc-6 & (Simonsen 1973) & & $\mathrm{X}$ \\
\hline FcTc-7 & (Simonsen 1970) & $\mathrm{X}$ & \\
\hline FcTc-8 & (Luebbers 1971) & & $\mathrm{X}$ \\
\hline FcTc-9 & (Luebbers 1971) & $\mathrm{X}$ & \\
\hline FcTd-1 & (Simonsen 1973) & $\mathrm{X}$ & \\
\hline FcTd-2 & (Simonsen 1970) & & $\mathrm{X}$ \\
\hline FcTe-1 & (Simonsen 1973) & $\mathrm{X}$ & \\
\hline FcTe-2 & (Simonsen 1973) & $X$ & \\
\hline FcTe-3 & (Simonsen 1973) & $X$ & \\
\hline FcTe-4 & (Simonsen 1973) & $\mathrm{X}$ & \\
\hline FcTe-5 & (Simonsen 1973) & & $\mathrm{X}$ \\
\hline FcTe-6 & (Simonsen 1970) & $\mathrm{X}$ & \\
\hline FcTe-7 & (Simonsen 1970) & & $X$ \\
\hline FcTe-8 & (Simonsen 1970) & & $\mathrm{X}$ \\
\hline FcTe-9 & (Simonsen 1970) & & $\mathrm{X}$ \\
\hline FcTf-2 & (Radke and Radke 2005) & & $X$ \\
\hline FcTg-1 & (Radke and Radke 2005) & & $\mathrm{X}$ \\
\hline FcTg-2 & (Radke and Radke 2005) & & $\mathrm{X}$ \\
\hline FdSt-5 & (Hobler and Dahm 1999) & & $\mathrm{X}$ \\
\hline
\end{tabular}




\begin{tabular}{|c|c|c|c|}
\hline Site Number & Reference & Shell Midden & $\begin{array}{l}\text { Fish } \\
\text { Trap }\end{array}$ \\
\hline FdSx-12 & (Hobler 1968) & & $\mathrm{X}$ \\
\hline FdSx-5 & (Luebbers 1971) & $\mathrm{X}$ & \\
\hline FdTa-16 & (Maxwell and Vincent 1996) & & $\mathrm{X}$ \\
\hline FdTa-2 & (Luebbers 1971) & & $\mathrm{X}$ \\
\hline FdTa-4 & (Luebbers 1971) & & $\mathrm{X}$ \\
\hline FdTa-5 & (Hobler 1977) & & $\mathrm{X}$ \\
\hline FdTa-7 & (Hobler 1977) & $\mathrm{X}$ & \\
\hline FdTb-1 & (Simonsen 1973) & $\mathrm{X}$ & \\
\hline FdTb-4 & (Simonsen 1989a) & $\mathrm{X}$ & \\
\hline FdTb-5 & (Simonsen 1989b) & & $\mathrm{X}$ \\
\hline FdTb-6 & (Simonsen 1989b) & $\mathrm{X}$ & \\
\hline FdTb-7 & (Simonsen 1989b) & & $X$ \\
\hline FdTc-2 & (Simonsen 1973) & & $X$ \\
\hline FdTc-4 & (Simonsen 1973) & $\mathrm{X}$ & \\
\hline FdTc-5 & (Mitchell 1969) & $\mathrm{X}$ & \\
\hline FdTc-6 & (Simonsen 1973) & & $X$ \\
\hline FdTc-7 & (Hill and Hill 1973) & $\mathrm{X}$ & \\
\hline FdTd-1 & (Simonsen 1973) & $\mathrm{X}$ & \\
\hline FdTd-2 & (Simonsen 1973) & $\mathrm{X}$ & \\
\hline FdTd-4 & (Simonsen 1973) & $\mathrm{X}$ & \\
\hline FdTe-11 & (Simonsen 1973) & & $\mathrm{X}$ \\
\hline FdTe-2 & (Simonsen 1973) & $\mathrm{X}$ & \\
\hline FdTe-3 & (Simonsen 1973) & & $\mathrm{X}$ \\
\hline FdTe-5 & (Simonsen 1973) & & $\mathrm{X}$ \\
\hline FdTe-6 & (Simonsen 1973) & $\mathrm{X}$ & \\
\hline FdTe-7 & (Simonsen 1973) & $\mathrm{X}$ & \\
\hline FdTe-8 & (Simonsen 1973) & $\mathrm{X}$ & \\
\hline FdTe-9 & (Simonsen 1973) & $\mathrm{X}$ & \\
\hline FdTg-1 & (Radke and Radke 2005) & & $\mathrm{X}$ \\
\hline FdTg-10 & (Radke and Radke 2005) & & $\mathrm{X}$ \\
\hline FdTg-11 & (Radke and Radke 2005) & & $\mathrm{X}$ \\
\hline FdTg-12 & (Radke and Radke 2005) & & $\mathrm{X}$ \\
\hline FdTg-13 & (Radke and Radke 2005) & & $\mathrm{X}$ \\
\hline FdTg-14 & (Radke and Radke 2005) & & $\mathrm{X}$ \\
\hline FdTg-15 & (Radke and Radke 2005) & & $\mathrm{X}$ \\
\hline FdTg-16 & (Radke and Radke 2005) & & $\mathrm{X}$ \\
\hline FdTg-17 & (Radke and Radke 2005) & & $\mathrm{X}$ \\
\hline FdTg-18 & (Radke and Radke 2005) & & $\mathrm{X}$ \\
\hline FdTg-19 & (Radke and Radke 2005) & & $\mathrm{X}$ \\
\hline FdTg-2 & (Radke and Radke 2005) & & $\mathrm{X}$ \\
\hline FdTg-20 & (Radke and Radke 2005) & & $\mathrm{X}$ \\
\hline FdTg-21 & (Radke and Radke 2005) & & $\mathrm{X}$ \\
\hline FdTg-22 & (Radke and Radke 2005) & & $\mathrm{X}$ \\
\hline FdTg-23 & (Radke and Radke 2005) & & $\mathrm{X}$ \\
\hline FdTg-24 & (Radke and Radke 2005) & & $\mathrm{X}$ \\
\hline FdTg-25 & (Radke and Radke 2005) & & $\mathrm{X}$ \\
\hline FdTg-26 & (Radke and Radke 2005) & & $\mathrm{X}$ \\
\hline
\end{tabular}




\begin{tabular}{|c|c|c|c|}
\hline Site Number & Reference & Shell Midden & Fish Trap \\
\hline FdTg-28 & (Radke and Radke 2005) & & $\mathrm{X}$ \\
\hline FdTg-27 & (Radke and Radke 2005) & & $\mathrm{X}$ \\
\hline FdTg-29 & (Radke and Radke 2005) & & $\mathrm{X}$ \\
\hline FdTg-3 & (Radke and Radke 2005) & & $\mathrm{X}$ \\
\hline FdTg-30 & (Radke and Radke 2005) & & $\mathrm{X}$ \\
\hline FdTg-31 & (Radke and Radke 2005) & & $\mathrm{X}$ \\
\hline FdTg-4 & (Radke and Radke 2005) & & $\mathrm{X}$ \\
\hline FdTg-5 & (Radke and Radke 2005) & & $\mathrm{X}$ \\
\hline FdTg-6 & (Anonymous 2001) & & $\mathrm{X}$ \\
\hline FdTg-7 & (Radke and Radke 2005) & & $X$ \\
\hline FdTg-8 & (Radke and Radke 2005) & & $\mathrm{X}$ \\
\hline FdTg-9 & (Radke and Radke 2005) & & $\mathrm{X}$ \\
\hline FdTh-1 & (Radke and Radke 2005) & & $\mathrm{X}$ \\
\hline FdTh-2 & (Radke and Radke 2005) & & $X$ \\
\hline FeSr-5 & (Simonsen 1989a) & $\mathrm{X}$ & \\
\hline FeSr-7 & (Hobler 1971) & $\mathrm{X}$ & \\
\hline FeSx-6 & (Simonsen 1989b) & & $\mathrm{X}$ \\
\hline FeTa-5 & (Simonsen 1989a) & & $X$ \\
\hline FeTa-6 & (Simonsen 1989b) & $\mathrm{X}$ & \\
\hline $\mathrm{FeTb}-2$ & (Simonsen 1989b) & & $X$ \\
\hline FeTc-1 & (Simonsen 1973) & & $\mathrm{X}$ \\
\hline FeTd-1 & (Simonsen 1973) & $\mathrm{X}$ & \\
\hline FeTd-2 & (Simonsen 1973) & $\mathrm{X}$ & \\
\hline FeTe-1 & (Simonsen 1973) & & $X$ \\
\hline FeTe-3 & (Somogyi-Csizmazia et al. 2010) & & $\mathrm{X}$ \\
\hline FeTe-4 & (Somogyi-Csizmazia et al. 2010) & & $\mathrm{X}$ \\
\hline FeTe-5 & (Somogyi-Csizmazia et al. 2010) & & $\mathrm{X}$ \\
\hline FeTe-6 & (Somogyi-Csizmazia et al. 2010) & & $\mathrm{X}$ \\
\hline FeTf-1 & (Simonsen 1973) & $\mathrm{X}$ & \\
\hline FeTf-2 & (Simonsen 1973) & & $\mathrm{X}$ \\
\hline FeTg-1 & (Simonsen 1973) & & $\mathrm{X}$ \\
\hline FeTg-2 & (Simonsen 1973) & & $\mathrm{X}$ \\
\hline FeTh-1 & (Mitchell 1969) & & $\mathrm{X}$ \\
\hline FeTh-10 & (Radke and Radke 2005) & & $\mathrm{X}$ \\
\hline FeTh-11 & (Radke and Radke 2005) & & $\mathrm{X}$ \\
\hline FeTh-12 & (Radke and Radke 2005) & & $\mathrm{X}$ \\
\hline FeTh-13 & (Radke and Radke 2005) & & $\mathrm{X}$ \\
\hline FeTh-14 & (Radke and Radke 2005) & & $\mathrm{X}$ \\
\hline FeTh-8 & (Radke and Radke 2005) & & $\mathrm{X}$ \\
\hline FeTh-9 & (Radke and Radke 2005) & & $\mathrm{X}$ \\
\hline FfTa-1 & (Foster and Coombes 1980) & & $\mathrm{X}$ \\
\hline FfTa-2 & (Simonsen 1989a) & $\mathrm{X}$ & \\
\hline FfTd-5 & (Engisch et al. 2008) & $\mathrm{X}$ & \\
\hline FfTd-8 & (Somogyi-Csizmazia et al. 2010) & & $\mathrm{X}$ \\
\hline FfTe-1 & (Simonsen 1973) & & $\mathrm{X}$ \\
\hline FfTe-2 & (Somogyi-Csizmazia et al. 2010) & & $\mathrm{X}$ \\
\hline FfTe-3 & (Somogyi-Csizmazia et al. 2010) & & $\mathrm{X}$ \\
\hline
\end{tabular}




\begin{tabular}{|c|c|c|c|}
\hline Site Number & Reference & Shell Midden & Fish Trap \\
\hline FfTe-4 & (Somogyi-Csizmazia et al. 2010) & & $\mathrm{X}$ \\
\hline FfTe-5 & (Somogyi-Csizmazia et al. 2010) & & $\mathrm{X}$ \\
\hline FfTe-6 & (Somogyi-Csizmazia et al. 2010) & & $\mathrm{X}$ \\
\hline FfTf-1 & (Simonsen 1973) & & $\mathrm{X}$ \\
\hline FfTg-1 & (Simonsen 1973) & & $\mathrm{X}$ \\
\hline FgTc-1 & (Simonsen 1973) & & $\mathrm{X}$ \\
\hline FgTc-2 & (Simonsen 1973) & $\mathrm{X}$ & \\
\hline FgTd-1 & (Simonsen 1973) & & $\mathrm{X}$ \\
\hline FgTd-2 & (Simonsen 1973) & & $\mathrm{X}$ \\
\hline FgTe-1 & (Simonsen 1970) & $X$ & \\
\hline FgTf-1 & (Simonsen 1973) & & $\mathrm{X}$ \\
\hline FgTf-11 & (Bonner et al. 2001) & & $\mathrm{X}$ \\
\hline FgTf-2 & (Simonsen 1973) & & $\mathrm{X}$ \\
\hline FgTf-25 & (Eldridge and Robinson 2001) & & $\mathrm{X}$ \\
\hline FgTf-3 & (Wilson 1992) & $X$ & \\
\hline FgTg-1 & (Simonsen 1973) & & $\mathrm{X}$ \\
\hline FgTg-2 & (Simonsen 1973) & & $\mathrm{X}$ \\
\hline FgTg-3 & (Simonsen 1973) & & $\mathrm{X}$ \\
\hline FgTh-1 & (Simonsen 1973) & $\mathrm{X}$ & \\
\hline FgTh-2 & (Simonsen 1973) & & $\mathrm{X}$ \\
\hline FiTc-2 & (Mackie and Eldridge 1988) & $X$ & \\
\hline FiTc-3 & (Mackie and Eldridge 1988) & $\mathrm{X}$ & \\
\hline FiTc-4 & (Mackie and Eldridge 1988) & & $\mathrm{X}$ \\
\hline FiTd-13 & (Harrison and Farvacque 2014) & $X$ & \\
\hline FiTd-14 & (Harrison and Farvacque 2014) & $\mathrm{X}$ & \\
\hline FiTe-1 & (Wilson 1989) & $\mathrm{X}$ & \\
\hline FiTe-2 & (Simonsen 1997) & $\mathrm{X}$ & \\
\hline FiTf-1 & (Simonsen 1970) & $\mathrm{X}$ & \\
\hline FiTf-10 & (Shortland and Wilson 1997) & $\mathrm{X}$ & \\
\hline FiTf-2 & (Simonsen 1973) & $\mathrm{X}$ & \\
\hline FjTe-2 & (Harrison and Farvacque 2014) & $\mathrm{X}$ & \\
\hline FjTe-2 & (Simonsen 1973) & & \\
\hline FjTe-30 & (Harrison and Farvacque 2014) & $\mathrm{X}$ & \\
\hline FjTe-33 & (Harrison and Farvacque 2014) & $\mathrm{X}$ & \\
\hline FjTe-34 & (Harrison and Farvacque 2014) & $\mathrm{X}$ & \\
\hline FjTe-37 & (Harrison and Farvacque 2014) & $X$ & \\
\hline FjTf-1 & (Simonsen 1973) & $\mathrm{X}$ & \\
\hline FjTf-22 & (Hall 2004) & $\mathrm{X}$ & \\
\hline FjTf-3 & (Wilson 1993) & $\mathrm{X}$ & \\
\hline FjTg-1 & (Simonsen 1970) & $X$ & $\mathrm{X}$ \\
\hline FkTe-1 & (Howe 1993) & $\mathrm{X}$ & \\
\hline FkTe-32 & (Golder Associates Ltd. 2008) & $X$ & \\
\hline FkTf-1 & (Leen 1985) & $\mathrm{X}$ & \\
\hline FkTf-5 & (Simonsen 1970) & $\mathrm{X}$ & \\
\hline FkTf-6 & (Simonsen 1973) & $\mathrm{X}$ & \\
\hline FlTd-1 & (Leen 1985) & $X$ & \\
\hline FlTe-24 & $\begin{array}{l}\text { (Stafford and Eldridge 1997; Streeter } \\
\text { 2006) }\end{array}$ & $\mathrm{X}$ & \\
\hline
\end{tabular}


Table A1.3 Observed and expected heterozygosity for North American grizzly bear populations. (Abbreviations: $\mathrm{H}_{\mathrm{E}}=$ expected heterozygosity; $\mathrm{H}_{\mathrm{O}}=$ observed heterozygosity; $\mathrm{N}=$ sample size)

\begin{tabular}{|l|l|l|l|}
\hline \hline Sampling Area & $\mathrm{N}$ & $\mathrm{H}_{\mathrm{O}}$ & $\mathrm{H}_{\mathrm{E}}$ \\
\hline Rockies South $^{1}$ & 99 & - & 0.67 \\
\hline Rockies North $^{1}$ & 122 & - & 0.66 \\
\hline Kluane $^{2}$ & 100 & 0.79 & 0.76 \\
\hline $\begin{array}{l}\text { Richardson }_{\text {Mountains }^{2}} \\
\text { Brooks Range }^{2}\end{array}$ & 238 & 0.77 & 0.76 \\
\hline Flathead Range $^{2}$ & 296 & 0.77 & 0.75 \\
\hline Selkirk South $^{1}$ & 80 & 0.69 & 0.69 \\
\hline Yellowstone & 43 & - & 0.54 \\
\hline G1 & 114 & 0.55 & 0.55 \\
\hline G2 & 31 & 0.60 & 0.56 \\
\hline G3 & 59 & 0.56 & 0.55 \\
\hline Proci & 38 & 0.70 & 0.68 \\
\hline
\end{tabular}

${ }^{1}$ Proctor (2005), ${ }^{2}$ Paetkau (1998) 


\section{LITERATURE CITED}

Anonymous, 2001. Site form for fish trap Weeteeam Bay (FdTg-6) on file at the BC Archaeology Branch, Victoria.

Apland, B. C., 1974. 1974 Survey of Portions of the Bella Bella Region, Permit 1974-0008. Report to the BC Archaeological Branch, Victoria.

Bedard, B., 1993. Tallheo Hotsprings Archaeological Survey, Nuxalk Heritage Project Permit 1993-0041. Nuxalk Heritage Project report submitted to the Nuxalk Nation and the BC Archaeology Branch, Victoria.

Blacklaws, R. W., 1980. Mackenzie Grease Trail Heritage Inventory and Assessment Project, Kluskus-Ulkatcho, Permit 1979-13. Ministry of Provincial Secretary and Government Services report submitted to the British Columbia Heriage Conservation Branch, Victoria.

Bonner, F., J. Anfossi, P. Dady, and D. Hall, 2001. Interfor North Coast Operations Archaeological Impact Assessments of Developments in the Scotia and Ecstall River Drainages and at Surf Inlet and Bear Lake, Princess Royal Island, Final Report of the 2000-2001 Field Season, Permit 2000-146. Millennia Research Limited report prepared for International Forest Products Ltd. and distributed to Hartley Bay Village Council, Kitasoo Band Council, LaxKw'alaams Indian Band, Allied Tsimshian Tribes Association, and the BC Archaeology Branch, Victoria.

Brown, A. P., 1989. Yeo Island Heritage Resource Impact Assessment, Permit 1989-0059. Report prepared for the Ministry of Forests Mid Coast Forest District and submitted to the Heiltsuk First Nation and the BC Archaeology Branch, Victoria.

Carlson, R. L., 1970. Kwatna Bay Excavations FaSu-2. Permit 1970-4a. Report on file with Archaeology Branch, Government of British Columbia. Victoria.

Carlson, R. L., 1971. Kwatna Report for Archaeological Sites and Advisory Board, Permit 197111. Report on File with Archaeology Branch, Government of British Columbia, Victoria.

Carlson, R. L., 1972. Report on archaeological excavations at Kwatna Inlet, Bella Coola, Permit 1972-11. Report on file with Archaeology Branch, government of British Columbia, Victoria. 
Dahm, I. R. and P. M. Hobler, 1996. Archaeological Impact Assessment of Development Sites 1 And 2, South Bentinck Arm, Permit 1996-262. Report submitted to the Nuxalk First Nation and the BC Archaeology Branch, Victoria.

Eldridge, M., and M. Robinson, 2001. Site form for fish trap Waap Wi Diis (FgTf-25) on file at the BC Archaeology Branch, Victoria.

Engisch, C., A. Bible, and O. Grant, 2008. Final Report for Archaeological Impact Assessments of Forestry Operations within the North Island - Central Coast Forest District in partial fulfillment of Heritage Inspection Permit 2006-86. Baseline Archaeological Services Report submitted to the Kitasoo Forest Company Limited/ Capacity Forest Management Limited Kitasoo Band Council, and the BC Archaeology Branch, Victoria.

Engisch, C., S. Dawe, A. Bible, O. Grant, B. Endo, and E. White, 2011. Final Report for Archaeological Impact Assessments of Forestry Operations for Bella Bella Asset Holdings Ltd. In Partial Fulfillment of Heritage Inspection Permit 2008-0387. Baseline Archaeology report prepared For Bella Bella Asset Holding Ltd., Heiltsuk First Nation and the BC Archaeology Branch, Victoria.

Finnis, M., M. Eldridge, and J. Carpenter, 1993. Detailed Impact Assessment of Archaeological Resources in Tom Bay and Pierce Bay, Central Coast, B.C., Permit 1993-0022. Millennia Research report submitted to the Central Coast Forest District and the BC Archaeology Branch, Victoria.

Foster, J., and D. Coombes, 1980. Site form for Fish trap FfTa-1 on file at the BC Archaeology Branch, Victoria.

Golder Associates Ltd., 2008. Final report on Archaeological Impact Assessments of forestry blocks and roads proposed by clients within the Kalum and North Coast Forest Districts, Permit 2006-193. Golder Associates report submitted to Lisims Forest Resources Ltd. Timber Baron Forest Products Northwest Timberlands Tyhee Forestry Consultants Kitselas Forest Products Haisla Resources Ltd., Kalum Forest District, Terrace, North Coast Forest District, Prince Rupert, Coast Tsimshian Resources Ltd. and BC Archaeology Branch, Victoria.

Hall, D., 2004. Archaeological Impact Assessments of BC Timber Sales, Seaward Business Unit, Prince Rupert Field Team's TSL A53180, Blocks A, B, C, E, F, H\& I, and an Archaeological Overview Assessment of TSL A53180, Block J, Mary Point, North Coast Forest District, Permit 2003-337. Arrowstone Archaeological Research and Consulting report submitted to the BC Archaeology Branch, Victoria.

Harrison, P., and R. m. Farvacque, 2014. Archaeological Impact Assessment of Proposed Kitimaat Renewable Energy Corp. Crab Europa Hydroelectric Project, Permit 2007-297. Archer CRM Partnership report submitted to the BC Archaeology Branch, Victoria. 
Hester, J. J., 1968. Report To The Provincial Museum, Victoria, British Columbia, Concerning Archaeological Investigations In The Bella Bella Region Conducted Under Permit No.1/68 During June And July 1968.

Hester, J. J., 1969. Prehistory of The Bella Bella Region, British Columbia, Permit 1969-0010. Report to the Archaeological Sites Advisory Board, Victoria.

Hill, B., and R. Hill, 1973. Petroglyph Sites From Queen Charlotte Strait To The Alaska Border: Petroglyph Survey, Permit 1973-34. Report submitted to the Archaeological Sites Advisory Board, Victoria.

Hobler, P. M., 1968. Archaeological Survey In The Ocean Falls - Bella Coola Area, May 15 July 5 1968, Permit 1968-8. A Preliminary Report To The Archaeological Sites Advisory Board, Victoria.

Hobler, P. M., 1971. Archaeological Work At Kimsquit: 1971, Permit 1971-25. Report submitted to the $\mathrm{BC}$ Archaeology Branch, Victoria.

Hobler, P. M., 1977. Archaeological Work In The Bella Bella Area, Permit 1977-13. Report submitted to the BC Archaeological Branch, Victoria.

Hobler, P. M., 1983. Archaeological Survey Of Alexander Mackenzie Provincial Park And Environs, British Columbia, Permit 1983-0011. Report on file with the BC Archaeology Branch, Victoria.

Hobler, P. M., and I. R. Dahm, 1999. The Skowquiltz Valley: History and Before. An Archaeological Overview Assessment, Dean Channel, Central Coast of B.C.

Howe, G., 1993. Archaeological Impact Assessment Unsurveyed Crown Foreshore And Upland, Pike Creek Area, Devastation Channel, B.C., Permit 1993-39. Arcas Consulting Archeologists Ltd. report prepared for Skeena Sawmills and the BC Archaeology Branch, Victoria.

Leen, D., 1985. A Preliminary Inventory of Haisla and Kitkiata Rock Art, Permit 1984-19. Report submitted to the Kitimat Heritage Advisory Commiesion and the Heritage Conservation Branch, Victoria.

Luebbers, R. A., 1971. Archeological Sampling At Namu, Permit 1971-12. Report on file at the BC Archaeology Branch, and the Department of Anthropology, University of Colorado, Boulder.

Mackie, Q. and M. Eldridge, 1988. Heritage Impact Assesment at Kiltuish Inlet, BC Permit 1988-8. Report Submitted to Kiltuish Forest Products Ltd. and the Heritage Conservation Branch. 
Maxwell, J., R. Chatan, J. Lindberg, and M. Eldridge, 1995a. Mid Coast Forest District: Fifteen Timber Sales Licence Cutblocks: Archaeological Inventory and Impact Assessment, Permit 1995-0169. Millennia Research Final Report prepared for Ministry of Forests, Mid Coast Forest District, Hagensborg, Nuxalk First Nation, Heiltsuk First Nation, Kitasoo First Nation, Oweekeno First Nation, Gwa'Sala-Nakwaxda'xw First Nation, and the BC Archaeology Branch, Victoria.

Maxwell, J., M. Eldridge, and B. Wilson, 1995b. Dean Channel, Nascall Bay, Archaeological Inventory And Impact Assessment, Permit 1995-56. Millennia Research Draft Final Report prepared for Dean Channel Developments Inc. Nuxalk First Nation, Heiltsuk First Nation and the BC Archaeology Branch, Victoria.

Maxwell, J., and R. Vincent, 1996. Archaeological Overview Assessment And Inventory of the northern end of Spiller Inlet, Ingram, Mooto, Polallie and Ellerslie Lake Drainage Areas: Final Report, Permit 1996-223. Millennia Research report submitted to Westem Forest Products Limited, Heiltsuk First Nation, and the BC Archaeology Branch, Victoria.

Maxwell, J., D. McLaren, M. Eldridge, R. Chattan, and T. Hoffmann, 1997. Heiltsuk Traditional Territory Archaeological Resource Overview Final Report Volume 1, Permit 1995-266. Millennia Research report On file with the Culture Library of the Ministry of Small Business, Tourism, and Culture, Victoria, B.C.

Mishra, S., 1975. Archaeological Survey In The Kitimat Area, Permit 1975-21. Report submitted to the Archaeological Sites Advisory Board, Victoria.

Mitchell, D. H., 1969. Site forms submitted to the Archaeological Sites and Advisory Board under Permit 1969-0026. University of Victoria Department of Anthropology.

Pomeroy, J. A., 1980. Bella Bella: Settlement and Subsistence. PhD dissertation. Department of Archaeology, Simon Fraser University.

Radke, B., and G. Radke, 2005. Archaeological Fish traps and site forms submitted to the BC Archaeology Branch. Site forms and map illustrations on file at the BC Archaeology Branch, Victoria.

Seymour, B., J. Carpenter, D. Windsor, C. White, and J. White, 1980. Archaeological Site form for FbTa-26, Martin's Island Bella Bella. Site form on file with the Heiltsuk Cultural Education Centre, Waglisla and the BC Archaeology Branch, Victoria.

Shortland, R., and I. R. Wilson, 1997. Archaeological Inventory And Impact Assessment: Gribbell Island, Kitkiata Inlet And Silver Creek, British Columbia, Permit 1996-173. Report prepared for Skeena Sawmills and submitted to the BC Archaeology Branch, Victoria. 
Simonsen, B.O., 1970. Archaeological Surveys And Other Activities of the Archaeological Sites Advisory Board, During 1970, Permit 1970-23. Report of the Field Director of the The Archaeological Sites Advisory Board, Victoria.

Simonsen, B.O., 1973. Archaeological Survey and Excavations in the Hecate Strait, Milbanke Sound Area of British Columbia, Permit 1969-5, National Museum of Man, Archaeological Survey of Canada, Ottawa.

Simonsen, B.O., 1989a. An archaeological survey of the Fjordland Recreational Area of the B.C. Central Coast, Permit 1989-0079b. Bastion Group, Heritage Consultants report submitted to B.C. Ministry of Parks Cariboo District Williams Lake and the BC Archaeology Branch, Victoria.

Simonsen, B.O., 1989b. Report on the results of an archaeological survey within the Hakai Recreation Area, Permit 1989-0079a. Bastion Group, Heritage Consultants report submitted to B.C. Ministry of Parks Cariboo District Williams Lake and the BC Archaeology Branch, Victoria.

Simonsen, B.O., 1992. Report on the Results of Archaeological/Ethnological Investigations at Strom Bay, Permit 1991-119. Bastion Group Heritage Consultants report submitted to Heiltsuk Indian Band and Ganapathi, Ashcroft, Cruickshank, Levine, Barristers \& Solicitors, Vancouver and the BC Archaeology Branch, Victoria.

Simonsen, B.O., 1997. Results of an Archaeological Impact Assessment Study of Proposed Timber Sale Areas, North Coast Forest District, Permit 1995-248. Bastion Group Heritage Consultants report submitted to the North Coast Forest District, Prince Rupert, B.C. and the Archaeology Branch, Victoria, BC.

Somogyi-Csizmazia, J., B. Fuhrer, S. Hodgson, and D. Neasloss, 2010. Non permit, Archaeological Survey Assessment and Preliminary Field Reconnaissance Carried out on Behalf of Kitasoo/Xaixais First Nation Kitasoo Spirit Bear Rainforest Conservancy, Laredo Inlet North Coast, $B C$. Site forms submitted to the BC Archaeology Branch, Victoria.

Stafford, J. W., and M. Eldridge, 1997. Archaeological Impact Assessment: Geo-Technical Drilling for Proposed Liquified Natural Gas Plant at Bish Cove, I.R. 6, Kitimat Arm, Permit 1997-23. Interim Report Prepared for Jacques Whitford Environmental Limited and submitted to the Haisla First Nation and the BC Archaeology Branch, Victoria.

Streeter, I., 2006. Archaeological Inventory and Impact Assessment: Kitimat Liquid Natural Gas Project Bish (Bees) Cove Kitimat, B.C., Heritage Conservation Act Site Inspection Permit 2005028. Report by I. R. Wilson Consultants Ltd.

White, E. X., 2006. Heiltsuk Stone Fish Traps: Products of my Ancestor's Labour. MA Thesis. Department of Archaeology, Simon Fraser University. 
White, E. X., 2011. Heiltsuk Stone Fish Traps on the Central Coast of British Columbia. in: Moss, M. L.and, Cannon, A. (Eds.), The Archaeology of North Pacific Fisheries, University of Alaska Press, Fairbanks, pp. 75-90.

Wilson, I. R., 1989. Heritage Resource Overview Assessment Proposed Logging Operations, Gardner Canal Area, Permit 1989-94. Report prepared for Wedeene River Contracting Company and submitted to the BC Archaeology Branch, Victoria.

Wilson, I. R., 1992. Heritage Resource Inventory And Impact Assessment: Drake Inlet Forestry Program, Permit 1992-125. Report prepared for Coast Strategies Corporation, Prince Rupert and the BC Archaeology Branch, Victoria.

Wilson, I. R., 1993. Heritage Resource Inventory: Goat Harbour And Fishtrap Bay Proposed Forestry Programs, Permit 1993-98. Report prepared for Coast Strategies Corporation, Prince Rupert and the BC Archaeology Branch, Victoria. 